\title{
Die teologiese agtergronde van die Voortrekkergelofte (1838)
}

\author{
A W G Raath \& E Erlank \\ Departement Staatsreg en Regsfilosofie \\ Universiteit van die Vrystaat
}

\begin{abstract}
The theological background of the Voortrekker Vow (1838)

An investigation into the theological background of the Voortrekter Vow of 1838 brings to light interexting perspectives on the sources that had an influence on the coming into existence of the Vow and its meaning. The preparatory research done by Prof A D Pont emphasises the fact that the Vow was exclusively based on sources from the Dutch Second Reformation. The understanding of its theological background can langely be traced to the work of Wilhelmus à Brakel. This was, however, not the only influential source dealing with vows of this mature and the body of the Vow cannot exclusively be understood from the work of Brakel alone. In this article several other authors from the Dutch Second Reformation who were also drawn upon for the formulation of the contents of the Vow are identified. An analysis of the historical and theological sources from which the Vow originated, enables us to give a definition of this wow in particular.
\end{abstract}

\section{INLEIDING}

Dit wil voorkom asof daar sedert die aflegging van die Voortrekkergelofte in Desember 1838 'n eeu en 'n half verloop het voordat indringende aandag aan die teologiese agtergronde daarvan gegee is. Aspekte wat met die peiling van die teologiese agtergrond van die Voortrekkergelofte (1838) verband hou, het sedert 1988 deur verskillende outeurs vanuit Hervormde kring aandag ontvang. Dit was veral die werk van A D Pont (1988:3853), J M G Storm (1989) en W A Dreyer (1999) wat gepoog het om lig op vraagstukke wat met die Voortrekkers se teologiese denke verband hou, te werp. Dit was egter in besonder Pont wat gepoog het om die teologiese agtergronde van die Voortrekkergelofte 
te peil. As agtergrond tot sy bespreking stel Pont dat dit opvallend is dat ten spyte van alles wat al "oor en rondom die Gelofte van Desember 1838 geskryf is, daar nog nie 'n poging aangewend is om die Gelofte te plaas en te verstaan teen die agtergrond van die Voortrekkers se godsdienstige denke en verstaan van 'n gelofte nie" (1988:38). Hy gaan voort: "Dit is opvallend dat so 'n openbare gelofte net in Desember 1838 voorgekom het, en dat hierdie vorm van toewyding net deur die kommando van Andries Pretorius gebruik word" (1988:38).

Waar Pont die teologiese invloede wat 'n effek op die Gelofte kon gehad het, na die Reformatoriese verbondsteologie terugvoer, wy hy uiteindelik die meeste aandag aan die bekende Nederlandse skrywer van die $18^{\circ}$ eeu, W à Brakel, se werk Redelyke Godtsdienst in welke de goddelyke waerheden des genaden-verbondts worden verklaert, tegen partyen beschermend ende tot de practyke aengedrongen (1736). Pont kom tot die gevolgtrekking dat dit waarskynlik lyk dat "die gedagte aan 'n gelofte ook vanuit sy (Andries Pretorius se) kennis van à Brakel se uiteensetting kan kom" (1988:51). Hy lewer soos volg kommentaar oor die aanvanklike onwilligheid van Sarel Cilliers om die Gelofte af te lê: "Dit is opvallend dat Sarel Cilliers se aanvanklike besware téén die aflê van 'n gelofte, in lyn lê met die opmerkings van à Brakel dat 'n gelofte nie ligtelik afgelê moet word nie. Daarom lyk dit waarskynlik dat Cilliers, nadat hy dié gedagte aanvaar het, eers die moontlikheid van die aflê van 'n gelofte by die laer op Danskraal aan die burgers genoem het, en dat die Gelofte self die eerste maal in die laer by die Wasbankrivier afgelê is" (1988:51) (sien ook die Voortrekkerherinneringe van Louis Jacobus Nel (1939:73) waar hy hy melding maak van die huiwering van Sarel Cilliers om die Gelofte af te lê, omdat hy bang was dat die Voortrekkers die Gelofte sou verontagsaam).

In talle opsigte het die werk van Pont, Storm en Dreyer die oog vir die belang van die peiling van die teologiese denke van die Voortrekkers geopen en grondleggende werk in hierdie verband gedoen. Van die vrae wat uit die navorsing van hierdie skrywers na vore kom, is onder andere of die Voortrekkergelofte slegs tot die werk van à Brakel teruggevoer kan word en of die werke van ander outeurs ook deur die Trekkers gelees is. Voorts is die vraag wat die aard van die literatuur was wat deur die Voortrekkers gelees is en wat die aard en inslag van die teologiese denke van die betrokke outeurs oor die aard van geloftes was. 
Ten einde dié vrae te beantwoord, word vervolgens op die aard van die literatuur wat in die Voortrekkergemeenskap gelees is en die standpunte van die besondere outeurs oor die teologiese agtergrond van geloftes gelet.

\section{BELOFTES EN GELOFTES BINNE DIE KONTEKS VAN DIE REFORMATORIESE VERBONDSTEOLOGIE}

Die agtergronde van die teologiese denke aan die Kaapse volksplanting vir die eerste twee eeue na Van Riebeeck se aankoms op 6 April 1652 aan die Kaap, kan nie voldoende begryp word sonder die verrekening van die verbondsteologie van Heinrich Bullinger en sy navolgers se invloed in hierdie verband nie. Dit was veral Bullinger wat reeds vanaf ongeveer 1537 'n duidelike verbondsteologie binne reformatoriese kring ontwikkel het (Baker 1980; McCoy en Baker 1991:25). Die werk wat tot 'n groot mate vir die vestiging van die reformatoriese verbondsteologie aan die Kaap verantwoordelik was, was Bullinger (1621) se preekbundel, bekend as sy Huys-boeck:

vijf decades, dat is, vijftich sermoonen, van de voomeemste hoofstucken der Christelicker religie, in dry deelen gescheyden .... Waer by mu van nieuws noch twee andere schoone wercke des seluigen autheurs gevoecht zijn, namelick, van den oorspronck, afcoemst ende voortganck aller dwalingen, die oyt by den heydenen, Joden ende Chrisenen geweest zijn ende noch hedensdaechs ghevonden worden ende, Van de Concilien ....; uut de latijnsche in ons Nederduytsche sprake overgeset, door I.G.

Dit is betekenisvol dat die cerste oktrooi wat deur die Staten Generaal op 20 Maart 1602 aan die VOC verleen is, nie melding gemaak het van enige verpligting van die VOC om die godsdienstige belange van die koloniste en inwoners van die gebiede wat verower of bestuur sou word, te behartig nie. Tog het die VOC hierdie taak vrywillig op homself geneem (Callenbach 1897:13; Vorster 1956:11). Vir hierdie doel het die VOC van sieketroosters en leraars gebruik gemaak (Raath 1999:176ev). In opdrag van die VOC het die sieketroosters ter see en aan die Kaapse volksplanting die taak gehad om, as publieke verkondigers van die Woord, die "conserveren van het publycke geloof" te behartig (Raath 1999:177ev). Die ems waarmee die VOC sy taak om die Gereformeende 
geloof te bevorder benader het, word deur Callenbach (1897:15), met verwysing na die opdragte van die Kompanjie aan die Goewerneur-Generaal van Indië soos volg verwoord:

... de predikanten en schoolmeesters op de vloot, om in Indië te blijven medegegaan sijnde, (te) stellen ter plaatse daar gij na goede informatie zult bevinden, dat zij den besten en meesten dienst zullen kunnen doen, goede zorg dragende, dat dezelve zich getrouwelijk en vredelijk in hunnen dienst, tot vermaning van de personen van de Comp. Aan land zijnde, en bevordering ter bekeering van de onkristenen en leering van derzelver jonge jeugd, mogen kwijten, ten einde de naam van Christus verbreid en der Comp. dienst mag bevordert worden na behooren.

Volgens die Beroep ende Instructiebrief voor de Sieckentroosteren gaende naer $O$ of $W I$, uitgereik deur die Classis van Amsterdam in 1636, moes die sieketroosters op gesette tye, benewens die sing van die Psalms, uit Gods Woord sommige hoofstukke, of ook enige goeie preek uit die Decades ( Huys-boeck) van Bullinger, die Kategismus Van Ursinus, of enige ander boek, opgestel deur enige leraar van die ware Christelike Gereformeerde Kerke, stigtelik aan die volk voorlees en dieselfde taak met gebed begin en eindig (Raath 1999:179). Van die werke wat die sieketrooster vir sy publieke geloofsversorging moes gebruik, was dit veral die Huys-boeck van Bullinger en Ursinus se kommentaar op die Heidelbergse Kategismus, in die vorm van sy Het schat-boek der Christelyke leere, ofte, uitlegginge over den catechismus ... vertaelt, ende met tafelen, ... verlicht, door ... Festus Hommius ... nu van nieuws oversien ... door Johannes Spiljardus ... (Leyden 1602), wat wye aanwending gehad het. Beide hierdie werke word in artikel 73 van die kerkorde voor de Bataviasche Gemeente Afgekondigd, 7 December 1643, genoem en van die werk van Bullinger verklaar Uytenbogaert (Van Troostenburg de Bruyn 1884:111) dat dit in die aanvang van die Hervorming meer gelees is as enige ander boek met uitsondering van die Bybel.

Die bekende Schat-boeck van Ursinus bestaan uit 'n verklaring van die Heidelbergse Kategismus in 'n reeks preke wat in die eerste 200 jaar na die volksplanting in Suid-Afrika baie gewild was (Du Toit 1947:32; Van Zyl 1991:174). In 'n skrywe van 20 April 1655 verklaar sieketrooster Willem Wylant vanuit die Kaap aan die Classis van 
Amsterdam dat hy Sondae 'n predikasie (van Bullinger) voorlees, die een Sondag 'n Evangelieteks en die volgende Sondag 'n verklaring van die Kategismus uit Ursinus (se Schat-boeck) of uit die werk van Lansbergius oor die Kategismus (Spoelstra 1906, I:3).

Die grondslae van Bullinger se standpunte oor die verbond ontwikkel hy reeds in 1534 in sy werk De Testamento seu Foedere Dei unico et aeterno. In hierdie werk beskryf Bullinger die verbond as die goddelike raamwerk vir die mens se bestaan, vanaf die grondlegging van die wêreld tot met die finale oordeel; die voorwaardes van die verbond vir die mens is "om te wandel voor My aangesig, dan sal jy opreg wees" (Gen. 17:1). Volgens Bullinger leer die Skrif in sy geheel en al sy dele die verbond en die voorwaardes daarvan. Die Dekaloog is 'n samevatting van hierdie voorwaardes. Die verbond wat deur die profete geleer is, is deur Christus hernu en bevestig; ook die apostels na Christus het dieselfde verbond verkondig as wat God met Abraham gesluit het (folio 24 (b) in McCoy en Baker 1991:117).

Alhoewel aanvaar kan word dat die invloed van Gereformeerde denkers soos Calvyn aan die Kaapse volksplanting besonder groot moes gewees het, is dit cok waar dat Bullinger se teologiese standpunte op 'n vroez stadium 'n belangrike rol aan die Kaapse volksplanting gespeel het (Raath 1999:186). Dit is voorts ook belangrik om daarop te let dat die teologiese uitgangspunte van Bullinger en Calvyn grootliks ooreenstem, behalwe dat Bullinger sy verbondsleer as selfstandige teologiese sleutel vir die interpretasie van die Skrif gebruik (Raath 1999:186). Daar moet egter op gewys word dat alle aanduidings bestaan dat dit eerder die teologiese verbondsleer, soos deur Bullinger geformuleer, was wat die grondslag en aanknopingspunt vir die verbondsteologie aan die Kaapse volksplanting was. Daarom is dit ongenuanseerd en twyfelagtig om die teologiese tradisie waarin die Kaapse grensboere en later die Voortrekkers gestaan het, as Calvinisties te tipeer, soos byvoorbeeld P.Strauss in sy werkie Geloftedag in die "Nuwe" Suid-Afrika (1994) impliseer. Hierdie verbondsvisie in die lyn van Bullinger en sy navolgers is veral deur die skrywers van die Nadere Reformasie as hermeneutiese sleutel vir die interpretasie van die Skrif gebruik en het die Gereformeerde verbondsleer toenemend die grondslag van die Reformatoriese teologie aan die Kaap gevorm. 
Reeds vanaf 1525 het Bullinger 'n duidelike verbondsinslag in sy teologiese werke geopenbaar. Dit was veral sy standpunte teenoor en kommentaar op die Anabaptisme wat die nuanses van die verbondsleer weerspieel (Baker 1988:135-152). In 1534 laat Bullinger 'n sistematiese viteensetting oor die verbondsleer, onder die titel De Testamento seu Foedere Dei unico et aeterno, die lig sien (McCoy en Baker 1991:101ev). Teen hierdie tyd het Bullinger reeds oor 'n uitgebreide lys publikasies wat met sy verbondsleer verband hou, beskik (Blanke en Leuschner 1990:326-330). McCoy en Baker (1991:12) beskryf hierdie werk van Bullinger as die bron van verbondsteologie in die Reformatoriese denke: "We speak of Bullinger's 1534 treatise, The One and Eternal Testament or Covenant of God, as the fountainhead of federalism. By that, we mean that it is a basic source of federal thought among the theologians, political philosophers, and practicing leaders in church and state. This influence was direct in the century following its publication and indirect during later times."

Vir Bullinger is daar 'n ewige verbond tussen God en mens en die hele Skrif is op die verbond gerig: "The entire sum of piety consists in these very brief main points of the covenant. Indeed, it is evident that nothing else was handed down to the saints of all ages, throughout the entire Scripture, other than what is included in these main points of the covenant ...."(16(a) in McCoy en Baker 1991:112). Volgens Bullinger is die verbond wat deur die profete geleer is, deur Christus hernu en bevestig; ook die apostels na Christus het dieselfde verbond verkondig as wat God met Abraham gesluit het (20(a) 24(b) in McCoy en Baker 1991:114-117). Bullinger sluit sy werk af met die standpunt dat die Christelike religie die oudste is omdat dit 'n verbondsluiting tussen God en Adam was. Die invloed wat Bullinger se verbondsteologie op die denke van sy tyd uitgeoefen het, word deur McCoy en Baker (1991:21) soos volg saamgevat:

Of all the published works of Bullinger The Covenant was the most important and influential. It was the seminal work of the federal tradition in Western thought and marks Bullinger as the initiator of this tradition in a very specific sense. This work quietly began a movement that made federal thought a hallmark of the Reformed tradition both on the Continent and in England and Scotland by the end of the sixteenth century. During this period, federal 
theology and political philosophy were emerging out of the heritage shaped by Bullinger and were evolving into forms that permeate modern democratic societies.

Van die invloed wat Bullinger se verbondsiening op die nuwe kolonie gehad het, skryf dieselfde outeurs: "It was, for example, this federal tradition, with explicit theological, ethical, and political dimensions, that was taken to the new world by the Puritans and used as the model for the colonies of New England. Bullinger's The Covenant was the fountainhead of federalism within the Reformed tradition and beyond. As Emmanuel Graf von Korff wrote many years ago, Bullinger was 'the first true federal theologian"" (McCoy en Baker 1991:21). Ook die Nederlandse gewestes onder beheer van die VOC sou onder die invloed van Bullinger se verbondsdenke kom, soos vervolgens sal blyk.

In sy Huys-boeck, deur die VOC vir die werksaamhede van die sieketroosters voorgeskryf, brei Bullinger in meer besonderhede oor die praktiese implikasies van die gelding van God se verbond en verbondswet in die samelewing uit: God volg in verbonde (soos ook in ander aangeleenthede) die wyse (van optrede) en gebruike van die mens (fol.114(a)(1):

\begin{abstract}
De menschen plegen hen-selven door verbonden gelijk met seer enge ende stercke banden/te verbinden in de gemeynschap ende vereeniginge eens lichaems ofte volcx waer door sy haer leven en alle goet onderlinge ghemeyn maken op dat hen wel gae/ende op dat sy tegen aller menschen onrecht ende gewelt/vry en seker zijn. En in dese verbonden wort duydtlic wtgedruckt/wie die zijn die door het verbont vereenicht werden/met wat conditien/ende hoe verre sy vereenicht zijn. Daerom doe God wilde zijn ghenade den menschelicken gheslachte verclaren/ende hem-selven geheel en alle zijne goeden ons ghemeyn make/ende in ons wtstorten/op dat het ons wel ginge/so maect hy een verbont met den mensche.
\end{abstract}

(Bullinger 1621: fol.114(a)(1)) 
Die verbondspartye is die lewende en ewige God, die almagtige en opperste Skepper, Bewaarder en Regeerder van alle dinge en die hele gelowige menslike geslag (Bullinger 1621: fol.114(a)(2)). Die verbond duur in ewigheid:

\begin{abstract}
Want hoewel daer vele dingen toe-gecomen zijn/in de vernieuwingen ende verclaringen des Verbonts/die als toevallige dingen daer na wederom zijn vergaen/voomemelick doe Christus is mensche geworde/so en is nochtans in de substancie ende in het wesen des Verbonts/niet verandert. Want God is altijts zijns volcx God: Hy begeert ende eyscht altijts getrouwe gehoorsaemheyt. Dwelck in het nieuwe Testament alderclaerlickst ghesien wort.
\end{abstract}

(Bullinger 1621:fol.114(a)(2))

Die voorwaardes van die verbond is tweërlei: eerstens wat God ons beloof en wat Hy ons, sy bondgenote, wil gee en wat ons van die Here verwag; tweedens wat die mens aan God verskuldig is en waarmee hy teenoor God verbonde is, wat beteken volle gehoorsaamheid aan die selfgenoegsame God: "God alleen is den mensche ghenoechsaem. Hy alleen can doen al wat den mensche staet te begheeren/ende tot de volmaeckte salichheyt dient" (Bullinger 1621: fol.114(a)(2)).

In sy De Testamento behandel Bullinger die beloftes van God net nadat hy die voorwaardes van die verbond bespreek het. Diegene wat deur verbonde verbind is, word, volgens Bullinger, deur bepaalde verordeninge saamgevoeg, sodat elk van die partye hul verpligtinge uit hoofde van die verbond kan ken, naamlik welke verpligtinge partye teenoor mekaar het en wat elkeen van die partye van die ander kan verwag (McCoy en Baker 1991:108 (fol.11(b)). God staan primêr binne die verbond en openbaar sy goddelike natuur, Hy toon aan ons wat Hy van ons verwag en wat vir die mens gepas is om te doen. God maak Homself aan ons bekend as: "the abundantly all-sufficient God, the hom of plenty" (McCoy en Baker 1991:109 (fol.12(a)). Dit beteken dat "he alone is that power and that good which suffices for humans. He who is in want of nothing supplies everything for everyone. Eternally he lives, moves, and acts from the divine energy itself' (McCoy en Baker 1991:109 (fol.12(a)). 
Die Godsbeskouing wat uit hierdie verbondskonteks na vore kom, beskryf Bullinger as 'n siening van die God van die hemel, daardie hoogste en ewige mag en majesteit, waardeur alle dinge bestaan en waarin alle dinge bestaan en beweeg. God wil die God van Abraham en van sy afstammelinge wees; God bied Homself aan as hulle Beskermer, Bondgenoot en Verlosser (McCoy en Baker 1991:110 (fol.14(a)).

Binne die konteks van die verbond spreek Bullinger hom in sy Huys-boeck (1621) wel oor die wedersydse beloftes tussen God en die mens uit, alhoewel dit nie sistematies onder een rubriek aangebied word nie. Bullinger beklemtoon die waarheid dat God sy beloftes hou en dat die mens wat op God hoop nie beskaam word nie: "David seyt: Onse vaders hebbe in $U$ gehoopt/sy hebbe gehoopt/en gy hebtse verlost. Sy hebbe tot $U$ geroepe/en sy zijn behouden geworden: sy hebben in U gehoopt en en zijn niet beschaemt gheworden" (1621:fol.99(4)). Met verwysing na Psalm 125, voeg Bullinger by: "De Heere is goet/salich is de man die in hem hoopt. Item: die inden Heere bertrouwe/die sulle onbewegelick zijn gelijc de berch Zyon/en sullen eeuwichlick blijven" (1621:fol.99(4)). In hul verdrukking dink die verdruktes aan die "clare ende rijke beloften Gods" en wend hul oog nie daarvan af en van die voorbeelde van die heiliges nie (1621: fol.100(b)(1)). Binne die konteks van die verbond kom velerlei beloftes van die kant van die mens as verbondsparty voor. Dit is in die besonder die "belofte-offers" wat die perspektief van geloftes van die kant van die mens na vore bring. Bullinger skryf soos volg daaroor: "Beloefde offerhanden waren/die wt belofte geoffert werden gelijk wanneer/yemant in perijckel zijnde/Gode eé offerhande beloeft hadde/so hy verlost wert. De offerhande die hy verlost zijnde/offerde was een beloefde offer. Dese quam inde wijse over eé met den danc-offer. Hier van wort meer geschreven Lev. Cap.7” (1621:fol.120(b)(2)).

Die rol van beloftes in samehang met die wet van God word vervolgens deur Bullinger bespreek. Hy maak melding van die talle verwysings na beloftes en lossing wat in die wet voorkom (veral Lev 27). Met die oog op God se gebooie is beloftes handelinge wat alleen aan God gemaak kan word: "Daerom waren dese beloften handelingen die God alleen geschiede/ende niet anders dan in heylige ende behoorlicke dingen" (1621:fol.120(b)(2)). Ligvaardige of onbehoorlike beloftes word nooit deur God goedgekeur of aangeneem nie; aanvaarbare beloftes mag alleen aan God gedoen word; beloftes moet betaal word; in die Skrif word nie genoem dat beloftes aan heiliges of aan 
enige ander skepsel gemaak mag word nie; dit moet binne die vermoe van die mens wat die belofte doen wees en nie teen die wil van God stry nie: "Wy en lesen niet dat eenich heylich mensche eenige beloften den heyligen ofte eenighen creaturen gedaen heeftofte yet beloeft heeft/dat in zijn macht niet en was/ofte teghen den wille Gods street/dien het belooft wert/ofte met des naesten onrecht vermengt was/ofte niet claerlick nut noch voorderlick en was" (1621: fol.121(a)(1)). Dit is waarskynlik dat eksemplare van Bullinger se Huys-boeck ook deur die Trekkers op die trekpad gelees is.

Die verbondsteologie van Bullinger (1504-1575) het mettertyd oor 'n bree front, veral onder sy studente, neerslag gevind. Sowel Zacharias Ursinus (1534-1583) as Caspar Olevianus (1536-1587) het onder Bullinger studeer. Van die wesenlike invloed wat in hierdie verband van Zurich uitgegaan het, skryf McCoy en Baker (1991:29): "In a very real sense, federalism flowed down from the Rhine and, over the course of the sixteenth and seventeenth centuries, became a major sector of theology within the Reformed churches of Switzerland, Germany, the Netherlands, Britain, and eventually New England." Dat Ursinus die verbondsteologie van Bullinger aanvaar het, blyk vir hiendie skrywers bo enige twyfel:

In his theology, Ursinus combined the thought of Melanchthon with that of Bullinger and developed a distinctive and innovative form of federalism. The covenant between God and human beings who have faith was, for Ursinus, the entire subject of Scripture. Following Bullinger, he understood the moral law to be included in God's command to Abraham to walk before God in righteousness, and he discovered the gospel in God's promise to bless all humanity through Abraham's seed.

Ursinus se verbondsteologie word in sy Schat-boeck verduidelik. In hierdie werk (1641 I: fol.69(a)(1)-(2) neem hy sy uitgangspunt daarin dat Christus as Middelaar die twistende partye van God en mens versoen. Hierdie versoening word in die Skrif die verbond of testament genoem, wat altyd in verband met die Middelaar verstaan moet word, 
want daer is gheen Middelaar/ofte hy is een Middelaer van eenigh Verbond/enn een Versoener van twistende partyen. Hierom na de leere van den Middelaer wordt bequamelick gestelt de leere van het Verbondt Godts/waer van voomamelijk ghevraecht wort: I. Wat het Verbondt Godts met de Menschen zy, welcke door den Middelaer ghemaeckt wordt: II. Ofter oock tusschen God ende de Menschen een Verbondt ghemaeckt kan worden sonder Middelaer; III. Hoe menigherhande het zy: ofter twee Verbonden zijn; IV. Hoe het oude ende nieuwe Verbodt ofte Testament over een komen, ende onderscheyden zijn.

Volgens Ursinus is 'n verbond, in die algemeen gesproke, 'n onderlinge coreenkoms en verbintenis van twee partye, waardeur die een hom aan die ander "verplig" tot sekere "dienste", tekens en seèls word verrig en aangebring tot meerdere bevestiging dat die belofte onverbreeklik is; hieruit kan nou die beskrywing van die verbond van God mèt die mens beskou word (1641:fol.69(a)(1)). Die verbond van God met die mens is 'n onderlinge ooreenkoms en verbintenis, waardeur God die mens verseker dat Hy hom genadig wil wees, sy sonde wil vergewe, 'n nuwe geregtigheid, die Heilige Gees en die ewige lewe skenk deur en ter wille van Sy Seun, die Middelaar Jesus Christus. Op sy beurt verplig die mens homself teenoor God tot geloof en boetvaardigheid, naamlik om hierdie groot weldade met 'n waaragtige geloof te ontvang en aan God ware gehoorsaamheid te bewys (1641 I: fol.69 (a)(1)-(2)).

Ursinus sien die verbond en testament as een saak, te wete die versoening met God, of deur hierdie onderlinge verpligtinge waardeur God ons sy genade met woorde en tekens beloof en weer van ons die belofte van gehoorsaamheid eis "ende dese versoeninghe wordt ghenaemt het VERBONDT, om de onderlinghe beloftenisse Gods ende der Menschen van sekere goederen te geven/ende van sekere diensten te bewysen" (1641 I: fol.69(a) (2)(b) (1)).

Die vraag hoe tussen God en mens 'n verbond gesluit kan word, antwoord Ursinus dat dit nie sou kon geskied sonder Middelaar nie, welke verbond deur Christus met sy dood bevestig is (1641 I: fol.69(b) (1)(2)). Die verbond van God.bestaan op grond 
van die primêre voorwaardes daarvan en as cén verbond in sowel die Nuwe as die Ou Testament: "Want hoe wel het inder daet maer een Verbondt en is/ende daer/eenerleye versoeninge met Godt is tot allen tyden: so is nochtans het Nieuwe Verbondt een ander/als het Oude: niet aengaende het wesen/maer aengaende de maniere der beloftenisse en bevestinghe" (1641 II: fol.38 (a) (1)).

Wat die Wet betref, verklaar Ursinus dat dit eerlikheid gebied: " Ende een Wet int gemeyn is een sententie ghebiedende eerlijcke dinge/de redelijcke natuere tot gehoorsaemheyt verplichtende met beloftenisse van belooninge/als de gehoorsaemheyt bewesen wort/en met dreyginghe der straffen/als de selve ingebroken wort" (1641 II: fol.105(b) (1)).

Binne die verbondsiening van Ursinus kom die onderwerp van beloftes/geloftes ook nie sistematies as afsondelike onderwerp voor nie, maar bring hy die kwessies wat daarmee verband hou by 'n viertal geleenthede ter sprake. Die eerste verwysing van Ursinus hou verband met die verklaring van die derde gebod (1685:II fol.114(b)). In verband met hierdie gebod, stel Ursinus dat ongeoorloofde eedswering ook insluit ligvaardige aflegging van ede. Dit sluit ook in ede en beloftes gedoen van sake wat onmoontlik of onbehoorlik is, soos die geval was met Jefta (Rig 11:30); met Dawid (1 Sam 25:22); met Herodes ((Mat 14:6); met die Jode (Hand 23:13) (1685 II: fol.114(b)).

In verband met die nakoming van die Tien Gebooie, spesifiek die vraag hoe dit verstaan moet word waar Christus ons beloof, dat indien ons die Vader in sy Naam aanbid, Hy ons dit sal gee, antwoord Ursinus soos volg:

Dat moet alleen verstaen worden van die dingen/die Godt belooft heeft te geven. Want het geloof siet op de beloftenisse/wanneer men bidt in den geloove om 't gene God belooft heef/soo verkrijght men 't selve. Nu en heeft ons Godt nergens belooft ons volkomen in de liefde te maken in dit leven: soo en kan men dan in den geloove daerom niet bidden; men verwerf het oock van den Heere niet. 
In sy bespreking van gebed stel Ursinus dit dat indien ons God aanroep, moet die mens uit hoofde van sy onwaardigheid of van die grootheid van sy nood, vas vertrou dat Hy nie alleen die mens se nood ken en hom kan help nie, maar ook die mens wil help. Hierdie vertroue moet steun, nie op die mens se waardigheid nie, maar op die beloftes van God (1685 II: fol.189(a)). Voorts oor die korrekte wyse van aanbidding van God, bring Ursinus die gedagte van die gelowige as bondgenoot van God na vore:

Leght mede af alle ondanckbaerhoyt des herten. (Deut 32:6). Ende neemt een vast voornemen om voortaen getrouwelick by den Heere te blijven (Act 11:23). Verbindt u meer ende meer aen uwen Godt: vernieuwt uw verbondt met Godt/ende uwen eedt, daar door ghy aen hem evenwel/als Zijn Bontgenoot/verplicht zijt (2Kron 15:9,15; Neh.9:38 en 10:29; Psalm 119:106). Ende versterckt $u$ hier toe met H.Geloften (Ps 50:14 en 66:13, 14) (1685 II: fol.190(a)

Daar is bree aanvaarding dat die Schat-boek van Ursinus oor 'n wye spektrum deur die Trekkers op die Trek saamgeneem en gelees is (Pretorius (1988:175); Carstens en Grobbelaar (1988:148)).

Die verbondsiening van Bullinger en Ursinus neem as vetrekpunt die beloftes wat van God uitgaan en die mens se (gelofte-) reaksie daarop. Die gelofte van Jakob in Genesis 28 moes in hierdie verband 'n belangrike perspektief gebied het op die wyse waarop die gelowige met geloftes op God se beloftes antwoord. God se verbondsbeloftes lui: "En kyk, Ek is met jou, en Ek sal jou bewaar oral waar jy heengaan, en Ek sal jou terugbring in hierdie land; want Ek sal jou nie verlaat nie, totdat Ek godoen het wat Ek jou gesê het" (Gen 28:15). Daarop volg Jakob se gelofte:

As God met my sal wees om my te bewaar op hierdie weg wat ek gaan, en aan my brood sal gee om te eet en klere om aan te trek, en ek behoue na die huis van my vader sal terugkom, dan sal die Here my God wees. En hierdie klip wat ek as gedenksteen opgerig het, sal 'n huis van God wees, en van alles wat $\mathrm{U}$ my gee, sal ek aan $\mathrm{U}$ sekerlik die tiendes afstaan.

(Gen 28:20-22) 
Jakob se gelofte eggo as 't ware God se belofte (Van Selms 1986:94). Daarby kom egter ook die kultiese vorm van Jakob se dien van God, naamlik 'n volgehoue, gedissiplineerde aanbidding en verering (erediens) en die konkrete daad in die vorm van die gee van tiendes; 'n erkenning dat die land behoort aan God as die ware eienaar (kyk Brueggeman 1983:248).

Uit die belofte-/geloftebeskouings van Bullinger en Ursinus is dit duidelik dat dit nie van die verbond losgemaak kan word nie. Die deurlopende lyn in die verbondsteologie van beide is dat die verbond alleen 'n gelofte wat vir God welgevallig is konstitueer en as sodanig nie van mekaar geskei kan word nie. God se beloftes is verbondsdade, daarom, in antwoord daarop maak gelowiges geloftes aan God. Sulke geloftes is nie kontrakte of beperkte ooreenkomste nie, maar oorgawe aan God, wat die hele lewe heroriënteer. Op grond van God se beloftes kan die gelowige hom met geloftes aan God verbind (vergelyk Jakob se gelofte in Gen 28).

\section{INVLOEDRYKE VERBONDSTEOLOẼ VAN DIE NADERE REFORMASIE WAT MOONTLIK 'N BYDRAE TOT DIE VOORTREKKERS SE VERSTAAN VAN DIE GELOFTE VAN 1838 GEMAAK HET}

'n Ondersoek na die standpunte van teoloe uit die tydperk van die Nadere Reformasie wat met die aflegging van geloftes aan God gedoen handel, vereis 'n opname van die sogenaamde "oude schrijvers" wat aan die voorposte deur die pioniersbevolking, onder andere die Voortrekkers, gelees is. Sulke studies is al op beperkte skaal deur C J Malan (1981) en W J van Zijl (1991) gedoen. Sodanige studies bied egter nie 'n voldoende oorsig oor die literatuur wat spesifiek in die tydperk rondom die Groot Trek gelees is nie. Voorts is beide studies nie bedoel om ' $\mathrm{n}$ volledige opname van die literatuur wat gelees is te bied nie.

'n Opname van die outeurs wat veral in die pioniersomstandighede gelees is en die frekwensie waarmee na hul werke verwys word, toon aan dat dit veral die werke van die volgende skrywers was wat gelees is: Wilhelmus à Brakel, à Marck, Balthasar Bekker, Borstius, Petrus Broes, Bunyan, D'Outrein, Erskine, Groenewegen, James 
Harvey, Hellenbroek, Petrus Immens, Kist, Johan Lasenius, Willem Teellinck, Coenrad Mel, Dirk Molenaar, Lambertus Myseras, John Newton, Bernardus Smytegeld, Willem Sluyter, Trommius, Zacharia Ursinus, Hieronymus van Alphen, Theodorus van der Groe, Helperus Ritzema van Lier, Jodokus van Lodenstein en Cornelius van Niel. Van hierdie outeurs handel à Brakel, Hellenbroek, D'Outrein, à Marck, Beukelman en Sjoerds spesifiek met geloftes en die voorwaardes en gelding daarvan. Vervolgens word gelet op die vraag na die mate waarin hierdie werke wel aan die Kaapse volksplanting gelees is en tot welke mate hulle deur die Trekkers vir hul geestelike versorging gebruik is. Hierby moet in gedagte gehou word dat die preekbundel van Heinrich Bullinger en die kategismuswerk van Zacharias Ursinus ook tydens die Groot Trek op die uittog meegeneem is (Carstens en Grobbelaar 1988:148). Daar moet wel op gewys word dat Johannes Calvyn in sy Institusie (4.13.1 ev) oor geloftes handel, maar dat geen getuienis gevind kon word dat dié werk voor en tydens die Groot Trek op uitgebreide wyse deur die grensboere gelees is nie.

\section{Wilhelmus à Brakel (1635-1711)}

Verwysings na Wilhelmus a Brakel duik by herhaling in die literatuur op. C J Malan (1981: 40) verklaar dat hy tot in die $20^{\circ}$ eeu baie gewild onder ons voorouers was. W J van Zijl (1991:181-184) stel dit as feit dat die "Nederduitse gereformeerde skrywer wie se werke die meeste in die bronne voorkom, is Wilhelmus à Brakel." Die werk wardeur à Brakel die meeste bekendheid verwerf het en waarmee hy ook een van die gewildste Nederduitse Gereformeerde "oude schrijvers" geword het, volgens Van Zijl (1991:182), is sy Logiké Latreia, dat is redelyke godtsdienst ... wat na alle aanduidings in die loop van die 18de eeu ongeveer 21 uitgawes en in die loop van die 19de eeu ook enkele herdrukke beleef het (Van Zijl 1991:235-236). Volgens Boekspieël van Suid-Afrika (1952:58) het, behalwe die Statebybel en Psalmboeke, die beskeie biblioteek van die Voortrekkers "in die gunstigste gevalle" bestaan het uit die preekbundels van à Brakel en Smytegelt en die stigtelike liedere van Sluiter en Groenewegen, liedere wat op selfgemaakte wysies gesing is. Van De Redelijke Godsdienst (in hierdie geval die uitgawe van 1747 te Rotterdam) word verklaar dat dit 'n werk was wat by die voorgeslag hoog in aansien was. Dit is selfs deur die trekboere in die Marico, Transvaal, in 1850 
gebruik om hul bewerings te staaf in hul verskille met dominee Andrew Murray (Boekspieël 1952:58).

B Spoelstra (1963:5) wys daarop dat à Brakel een van die outeurs was wat, in 'n tyd waarin die Gereformeerde belydenis al hoe meer losgelaat is, aan die ou Gereformeerde opvattings vasgehou het en dat sy werke in die tweede helfte van die $18^{\mathrm{e}}$ eeu deur die geisoleerde Doppers "gelees en herlees" is. Elders meld Spoelstra (1963:24) dat à Brakel, in onderskeiding van ander teologiese skrywers van hierdie tyd, een van diegene was wat deur die geïsoleerde pioniersbevolking as een van die "auteurs" beskryf is (sien ook J Chr Coetzee 1941:14-15). Hierdie mense het hulle ook op à Brakel beroep met betrekking tot die godsdienstige meningsverskille van die tyd (Spoelstra 1963:52). In 1858 beroep die bekende kerkfiguur in die ZAR H J Bosman hom op à Brakel in sy argument dat die kerklike soewereiniteit teenoor die staat gehandhaaf moet word (Spoelstra 1963:125). Kort daarna doen ook Paul Kruger 'n beroep op à Brakel in die stryd oor die verhouding tussen kerk en staat in die ZAR (Spoelstra 1963:129). Op 10 Maart 1858 skryf J J Venter na Nederland dat 'n gedeelte van die gemeente Bloemfontein en mense uit die Kaapkolonie 'n leraar sou onderhou wat weer die leer soos Smytegeld, Mel, à Brakel, Van Leeuenaarde en "diergelijke geestelijke schrijvers" verkondig. Derhalwe verpand hy al sy goedere as 'n waarborg vir die traktement van die predikant, indien hy maar net weer "in Godshuijs met vreugde kan gaan" (Spoelstra 1963:159; Raath 2000:36-37). L J Strauss (1986) meld verskeie verwysings in die loop van die vorige eeu waar na à Brakel se werke, veral dan na die Redelyke Godsdienst, verwys is binne die konteks van gesaghebbende teologiese werke deur ons voorouers gebruik.

Spesifiek wat die Vootrekkertyd betref, aanvaar A D Pont (1988:38 ev) dat à Brakel een van die "oude schrijvers was wat deur die Voortrekkers en die pioniers in die Oorvaalse gereeld geraadpleeg en nagevors is". W A Dreyer (1999: 70) skryf: “As dogmatiekhandboek was die Redelyke Godsdienst van Wilhelmus à Brakel gewild ... Strauss toon aan dat à Brakel groot invloed gehad het. Verskillende fragmentariese verwysings, onder andere deur ds Dirk van der Hoff, dui daarop dat die Calvinistiese denke wat ons by die Voortrekkers vind, waarskynlik beïnvloed is deur à Brakel .... Dit blyk ook duidelik uit die invloed wat à Brakel op die Gelofte van 1838 gehad het ...." Elders stel Dreyer (1999:77) eksplisiet dat à Brakel "een van die oude schrijvers (was) 
wat dikwels deur die Voortrekkers geraadpleeg is." Ander skrywers, soos Carstens en Grobbelaar (1988:147-148) handhaaf ongekwalifiseerd dat die Redelyke Godsdienst van à Brakel deur die Voortrekkers gebruik is en in "die vorige eeu bestendig versprei" is; Pretorius (1988:175) meen dat dit 'n standaardwerk van die Voortrekkers was en Venter (1982:210-211) dat dit een van die basiese werke was wat op die trekpad saamgegaan het. Hierdie afleidings word deur mededelings van persone wat op die Trek was ondersteun. Susanna Smit, suster van Gerrit Maritz en eggenote van die Voortrekkerprediker Erasmus Smit, verwys 'eksplisiet na die skrywer à Brakel (Dagboeke).

Sonder huiwering kan dus aanvaar word dat à Brakel se Redelijke Godsdienst een van die werke was wat deur die Trekkers gelees en vir die inkleding van hul godsdienstige en maatskaplike lewe gebruik is.

\section{Abraham Hellenbroek (1658-1731)}

Van Zijl (1991:161 ev) meld dat die katkisasieboek van Hellenbroek vanaf die middel van diel8de eeu af aan die Kaap bekend moes gewees het. Hy gaan voort om te stel dat van al sy werke sy katkisasieboek Voorbeeld der Goddelijke waarheden voor eenvoudigen, die zich bereiden tot de belijdenis des geloofs, om van buiten te leren en als een a b om verder te leren, wat vir die eertse keer in 1706 in Rotterdam verskyn het, aan Hellenbroek die grootste bekendheid besorg het. Na Hellenbroek se dood in 1731 is sy katkisasieboek aangevul met 'n hoofstuk oor die Raad van Vrede, 'n Kort Begrip en 'n Register van die vernaamste dwalings buite die Gereformeerde Kerk. Die antwoorde is uitgebrei met vermelding van die toepaslike Bybeltekste, terwyl daar by die uitgebreide sogenaamde "Groot Hellenbroek" ook 'n woord aan die "Geliefde Leerling" gerig is (Van Zijl 1991:162).

Dié werk van Hellenbroek is vir bykans twee eeue in ons land onder die pioniers veelvuldig gebruik omdat dit 'n omvattende inleiding tot die gereformeerde geloofsleer is en in alle opsigte die streng gereformeerde standpunt volkome betroubaar weergee. Dit verklaar in belangrike opsigte waarom die werke van Hellenbroek so wyd aan die Kaap gelees is. Volgens J Chris Coetzee (1941:14) het die Voortrekkers se onderrig in die geloofswaarhede veral geskied aan die hand van die boeke van Abraham Hellenbroek, veral sy kleine en dubbele Voorbeeld der Goddelijke Waarheden, van Het Kort Begrip 
der Christelike Leer en van die Heidelbergsche Katechismus self. Van die werk Voorbeeld der Goddelijken waarheden word in die Boekspieël (1952:60) vermeld dat dit 'n boek is "wat oor 'n lang tydperk baie algemeen in gebruik was." Van sy werk Korte en eenvoudige Catechizatie, over het voorbeeld der Godlyke waarheden ..., waarvan die sesde druk reeds in 1799 deur Jan Nupoort, te Utrecht, Paddenburg, uitgegee is, meld dieselfde bron dat 'n minder uitgebreide uitgawe, bekend as die "Enkele Hellenbroek" aan die Kaap gebruik is, veral ook in die geval van slawe wat Christene wou word (Boekspieêl 1952:60). 'n Derde werk wat deur die Boekspieel vermeld word is Hellenbrock se Bybelsche Keurstoffen (die 1744-uitgawe).

Die gebruiklike boek by katkisasielesse was Hellenbroek se Kort begrip der Christelijke religie, 'n verkorte weergawe van die Heidelbergse Kategismus. In 'n berig aan Ryk Tulbagh vertel die landdros van Stellenbosch in 1770 van sy reis na Swellendam en dat hy daar in die distrik "eenige schoolboeken en onder anderen een den titul voerende: Voorbeelden der goddelycke waarheden door den Eerw. Heer A Hellenbroek ...." gevind het (Boekspieel 1952:60). Volgens dieselfde bron het M J Stucki opgemerk dat Hellenbroek se vraeboek te Wellington in die skole tot in 1870 gebruik is (op 60). Dat Hellenbroek se werke reeds voor 1795 aan die Kaapse volksplanting gelees is, blyk uit die herinneringe van Petrus Borchardus Borcherds (1907:17) waar hy vertel hoe hy onder die leraar George Knoop onderwys ontvang het: "Ik ontving van hem onderwijs in lezen, schrijven, cijferen, den heidelbergschen Catechismus en 'Hellenbroek', cen boek, dat vragen en antwoorden bevatte omtrent het geheele godsdienstige stelsel, zooals dat in onze kerk onderwezen wordt en in gebruik is als aanstaande lidmaten van de kerk aangenomen willen worden."

Uit die mond van die Potgieter-voorgeslagte teken T A N Potgieter op hoe een van die familielede, Jacobus Philipus Potgieter, ongeveer 1848, met die oog op sy belydenisaflegging eers Hellenbroek se vraeboek moes baasraak:

(N)ouw ja nouw koop ik 'n vraage boek en die is de hellem broek. (D)it is een boek 200 dik als de beibel geschiedenes, die moet ik eut mij hoof leer zoo als min mensse nu On-se Vader ken. (O)or ses maande wel ik nouw in gaan en ik 
hoor di jong nooinki wel dan ook in gaan. (I)k vat toe ook in. (M)aar glo ver mij daar lê nou leer nag en dag. En kom ook mooi door."

(A J van der Walt 1920:67; sien ook B Spoelstra 1922:62)

Willem J van Zijl (1991:246-247) se opname van die verspreiding van Hellenbroek se werke toon 'n verbasende uitgestrekte gebied, sowel as 'n wye aantal werke van dié skrywer. Dit șiuit in sy werk Bybelsche keurstoffen (oudste druk 1733), De evangelische Jesaya (oudste druk 1702-1710), Het Hooglied van Salomo (1718-1720), De kruistriomph van vorst Messias (oudste druk 1737), Nuttige Mengelstoffen (oudste druk 1742) en Voorbeeld der goddelijke waarheden voor eenvoudigen (oudste druk 1733).

Verskillende outeurs maak spesifiek melding van werke van Hellenbroek wat op die trekpad deur die Voortrekkers gebruik is. Carstens en Grobbelaar (1988:146) meld dat die vraeboek wat deur die Trekkers gebruik is, die "kleiner Hellenbroek" genoem is. Indien ' $n$ katkisant hierdie boek van buite geken het, is so 'n persoon as baie intelligent beskou. Pretorius (1988:175) noem Hellenbroek se De geloofsleer voor onze Christelijke Jeugd as 'n werk wat die Trekkers ter hand gehad het. Dieselfde werk word ook deur E A Venter (1982:218) as Trekkerliteratuur genoem, terwyl P B van der Watt (1981) slegs na die "klein boekie" van Hellenbroek verwys, bedoelende warskynlik sy vraeboek. Sowel A D Pont (1988:50) as J M G Storm (1989:21) aanvaar dat die werke (veral die katkisasieboeke) van Hellenbroek binne die invloedskring van die Voortrekkers gebruik is.

Daar bestaan weinig twyfel dat die werke van Hellenbroek op die voorposte, in die tyd voorafgaande aan die Trek, en later op die Trek 'n belangrike deel van die godsdienstige boekery van die Voortrekkers uitgemaak het (sien ook B Spoelstra 1922:62 en I D Bosman 1938:177). Dit is ook logies om te aanvaar dat hierdie werke, soos dié van à Brakel en ander "oude schrijvers" intensief deur die Trekkers gelees is. Dat die werke van Hellenbroek in dieselfde asem as die gesag van à Brakel genoem is, blyk uit die mededelings van dominee Dirk van der Hoff kort na sy aankoms in die Transvaalse Republiek in 1852 aangaande die onderwystoestande in die jong republiek: "De onkunde onder het opkoomend geslacht, dat is te zeggen tot den ouderdom van $\mathbf{4 0}$ jaar toe, is verregaand; natururlyk met enkele uitzonderingen. De oudere van dagen die in de 
Kolonie nog godsdienstige opvoeding genoten hebben, zyn nog eenigszins ervaren; dat is te zeggen: het grootste gedeelte zweert by à Brakel en Hellenbroek ..." (Lugtenburg 1925:45).

\section{Bernardus Smytegelt (1665-1739)}

In sy opnames van die werke van Smytegelt wat in die $18^{\circ}$ en $19^{e}$ eeue aan die Kaap in omloop was, vind Willem J.van Zijl (1991:187ev, 267-268) 'n eksemplaar van Zestien uitmuntende predikatiën ... (1713-uitgawe); Des Christens eenige troost ... (1742 en 1766-uitgawes onderskeidelik); Een woord op syn tyd ... (1745 en 1761-uitgawes onderskeidelik); Des Christens heil en cieraat ... (1740-uitgawe) en Keurstoffen ... (1764uitgawe) en Het gekrookte riet ... (1744-uitgawe). Die Voortrekkermueseum te Pietermaritzburg beskik oor 'n eksemplaar van Smytegelt se Des Christens heil en cieraat ... (1744-uitgawe). Hierdie verspreiding van Smytegelt se werke noop Van Zijl om die gevolgtrekking te maak dat van sy werke reeds teen die middel van die $18^{e}$ eeu vanaf die Kaap tot by die verste uithoek van die land gelees is (1991:188).

P S de Jongh (1977:118) verduidelik die gebruik van Calvinistiese literatuur deur die Voortrekkerprediker Erasmus Smit soos volg:

Smit het homself as Calvinisties en Hervormd of Nedenduits Gereformeerd beskou en daarvolgens sy prediking ingerig. Hy het sy preke voorberei met behulp van veral die Heidelbergse Kategismus en die Bybelse konkordansie van A Trommius ... Laasgenoemde was 'n Bybelse woordeboek wat sy swaer, Stephanus Maritz, vir hom uit die Kolonie saamgebring het en wat 50 riksdaalders gekos het. Waarskynlik het hy ook ander bekende preekbundels, onder andere Helperus Ritzema van Lier se eenvoudige Leereden en Bernardus Smytegelt se Des Christens Heil en Cieraat, wat in sy swaer se besit was, gebruik.

W A Dreyer (1999:70) en J Chris Coetzee (1941:14, 15) meld sonder weifeling dat Smytegelt se preekbundels wel deur die Voortrekkers gelees is (vgl ook C Potgieter, N H Theunissen 1938:17 \& S du Toit 1947 II:249). J M G Storm (1989:21) skryf: "Benewens die Bybel is verskeie boeke van skriftuurlike en stigtelike aard en ook liederebundels en 
gebedeboeke deur die boeregesinne gebruik. Bekende skrywers wie se werke gelees is, is onder andere Wilhelmus í Brakel (moet wees à Brakel), Bernardus Smijtegeld, Coenraad Mel en A Hellenbroek." Bevestiging vir die feit dat die Voortrekker- en Trekboerpioniers van Smytegelt se werke gebruik gemaak het, is ook by B Spoelstra (1963:5, 24 ev, 51, 159 \& 165) te vinde, asook in B Kruger $(1957: 68,75,76,124,125,241)$. Lourens de Klerk (1818:256) maak in sy Voortrekkerherinneringe eksplisiet melding van 'n predikasieboek van Smytegelt, wat ook 'n lewensbeskrywing bevat, wat deur die Trekkers gebruik is. Die smaak en voorkeur van die Trekkers het ook met hul voorkeur vir die "oude schrijvers" verband gehou. A H Lugtenburg (1925:10) beskryf die gebruik van die werke van Smytegelt as deel van hierdie lewenswyse soos volg:

Die huisraad was hier eenvoudig en selfgemaak, 'n emmer water en 'n kalbas het die tafelkristal vervang en die velskoen, velbroek en velthoed was hier in hulle natuurlike huis, hoewel daar nog altijd die kisklere was. Die boekery was ingekrimp tot Bybel, 'n paar Psalmboeke, à Brakel, Smytegeld, 'n $A B C$ boek en die Trap der Jeugd. Hulle rykdom was vee, en die kondiesie daarvan het hulle beweginge beinvloed. Was dit gesond en het die grensboer daarby 'n goeie vrou en 'n lewendige klompie kinders gehad, dan was sy geluk volmaak.

\section{Johannes à Marck (1603-1665)}

In sy opname van werke van die Nadere Reformasie wat in Suid-Afrika gelees is en die verspreiding van sodanige werke, kon Willem J van Zijl (1991:257) die werke De gecruycighde Christus, ofte, XXXV texten van't Lyden ende sterven Jesu Christi in dewelcke dat selve uyt de vier evangelisten jaerlicks verclaert wort in de gemeynte des Heeren tot Groningen ... (1656-uitgawe) en Geestelijke hartsterking tegen der geloovigen geestelijken strijd, en hunne zwakheid, in XV. Predikaatsijen, meest bij't Avondmaal voortijds gehouden (1771-uitgawe) in boekeversamelings opspoor.

T N Hanekom (1951:93) het geen twyfel dat die werke van à Malk i 'ie loop van die $18^{e}$ eeu aan die Kaap gebruik is nie: "As godsdienstige leesstof was natuurlik altyd die ou Staten-Bijbel, met sy kanttekeninge, byderhand, saam met boeke van à Brakel, Smytegelt, Coenrad Mel, à Marck en Stapper (moet wees Stapfer), maklik te vind op 'n rak in die boerewoning of in die wakis van die trekboer." 


\section{Johannes d'Outrein (1662-1722)}

Die verspreiding van werke van hierdie outeur in Suid-Afrika lewer, volgens Willem J van Zijl (1991:261) die volgende op: De gelykenissen van den verloren zoon ... en onregtveerdigen rentmeester ... beneffens nog andere stoffen ... verklaard en toegepast ... (1692-uitgawe); Korte schets der godlyke waarheden soo als die in haar natuurlyke ordre te samen geschakeld zijn ... (1703-uitgawe); Het gouden kleinoot van de leere der waarheid die naar de godsaligheid is, vervattet in den heidelbergschen catechismus nader uitgebreidt, opgeheldert en betoogt door Johannes d'Outrein. ... Verb.en verm. .... 2 de dr., daar bygevoegt de uit het Hoogduitsch ... vertaalde aanmerkingen en vermerderingen van Frederik Adolph Lampe (1724-uitgawe); De sendbrief van Paulus aan de Hebreen, ontleedet, uitgebreid en verklaart ... (1711-1717-uitgawe); De tabernakel van Moses, in synen oorsprong ... gestalte, vaten, cieraad ... (1715-uitgawe).

In Boekspieël (1952:56-57) word daarop gewys dat D'Outrein se Korte schets der Goddelyke waarheyd (1700-uitgawe) onder die boeke van Adam Tas aan die begin van die $18^{\mathrm{e}}$ eeu te vinde was. Die werk De gelykenissen van den verloren zoon en onregtvaardigen rentmeester (1692-uitgawe) was in die tyd van Adam Tas goed bekend aan die Kaap. Die kerkraad van Drakenstein het byvoorbeeld in Januarie 1717 by goewerneur Chavonnes aangeklop om "50 Bijbels in quarto; 10 Schetsen van D'Outrein en 100 Oostrums over de Heidelbergsche Categismus" namens hulle te bestel. Omstreeks 1790 kom drie van D'Outrein se werke in 'n boedelopgaaf voor.

B R Krüger $(1957: 67-68,75)$ meld dat die gebruik van stigtelike literatuur onder die sogenaamde "Doppers" (afgelez grensboere) in die tyd voor die Groot Trek hulle die nodige onderskeidingsvermoE laat behou het. Volgens Krüger het die volgende skrywers in hierdie kategorie voorgekom: W à Brakel, Coenraad Mel, Bernardus Smytegelt en D'Outrein. S du Toit (1947:249) noem ook D'Outrein se werke in dieselfde asem as dié van outeurs soos à Brakel en Smytegelt, synde van die belangrike leesstof wat deur die grenspioniers gelees is.

\section{Joannes Beukelman (1704-1757)}

Alhoewel Beukelman se naam gewoonlik nie in dieselfde asem as dié van ander outeurs van die Nadere Reformasie genoem word wat 'n belangrike impak op die grensbevolking 
in Suid-Afrika gehad het nie, toon die opname van Willem J van Zijl (1991:232-233) 'n hele aantal van sy werke wat in die loop van die 18de eeu in die Kaap in omloop moes gewees het. Die werke van hierdie outeur wat deur Van Zijl opgespoor is, is die volgende: De leere der waarheid tot godzaligheid, of, volledige verklaaring over den heidelbergschen catechismus, in twee en vyftig leerreden ... (1774-uitgawe); De lydende en verheerlykte Immanuël; of, volledige verklaaring over alle de lydens en feeststoffen, in negen en vyftig leerredenen ... waaar by gevoegt zyn drie leerredenen over den lofzang Simeons en eene belydenis-predikatie (1775-uitgawe) en Uitgelezene keurstoffen, of, leereden over verscheidene texten, zoo des Ouden als des Nieuwen testaments, ... (17751776-uitgawe).

In sy Voortrekkerherinneringe maak Lourens de Klerk (Preller 1918:256) spesifiek melding van die werk van Beukelman wat op die Trek gebruik is:

Ander bekende godsdienstige werke was die s.g. 'auteur-boeke', meestal predikasie boeke met aantekeninge, soos die 'Donderslag der Goddelozen', met gebede vir énige dag van die jaar en énige geležntheid of Bernardus Smijtegelt, 'n predikasie-boek met lewensbeskrijwing van die auteur, verder Petrus (moet wees Joannes) Beukelman en à Brakel, ook 'n predikasie boek. Almaal was ou-druk.

\section{Foeke Sjoerds (1713-1770)}

Een van die merkwaardigste outeurs van die Nadere Reformasie was die outodidak en skrywer Foeke Sjoerds; skoenmaker en later skoolmeester. Uit sy hand verskyn vanaf 1761 tot 1765 in drie dele die Kort vertoog van den Staat en de geschiedenissen der Kerke, van de Scheppinge tot op Christus, ... Alles op den juisten rang van zijnen tijd geplaast, en in eene naauwkeurige aaneenschakeling met de Geschiedenissen der meest bekende Oude Volken. Die stof vir hierdie werk put hy uit die Ou Testament en uit allerlei geskrifte oor die antieke geskiedenis.

As vervolg hierop skryf Sjoerds die Kort Vertoog enz. Der kerke des Nieuwen Testaments van Christus geboorte tot op den tegenwoordigen tijd, vergeleken met de voornaamste waereldlijke Geschiedenissen. Sjoerds het 'n besondere bewondering vir Voetius gekoester en was teen die pietisties-mistieke strominge in die teologie gekant. 
Hy het sowel die cartesianisme as die teologie van Balthasar Bekker bestry en die invloed van Voltaire as "zielverpestend" beskou (Christelijke Encyclopaedie VI:378(2)-379(1)).

Alhoewel geen verwysings na Sjoerds se werke in die Voortrekkerliteratuur voorkom nie, is die eksemplaar van sy Kort Vertoog van den Staat en de Geschiedenissen der Kerke, van de Scheppinge tot op Christus ... wat ter hand is wel een wat waarskynlik uit die vroee Gereformeerde tradisie aan die Kaap kom en as sodanig heel moontlik in die loop van die 18de eeu wel aan die Kaap gebruik is.

\section{Abraham Trommius (1633-1719)}

Die bekende konkordansie van Trommius is deur Willem J van Zijl (1991:270) in verskeie boekeversamelings opgespoor. Uitgawes van 1685-1691, 1672, 1750 en 1751 is deur hom in boekerye aangetref. Dié werk se titel lui Volkomene Nederlandsche concordantie ofte woordregister des Ouden en Nieuwen Testaments. In die Boekspieël word 'n eksemplaar van 1672 gerapporteer. Erasmus Smit, die predikant van die Voortrekkers, het hom oor hierdie Bybelse woordeboek verheug toe Stephanus Maritz dit uit die Kaapkolonie saamgebring het. 'n Eksemplaar van dié werk kom ook in die versameling van die Voortrekkermuseum in Pietermaritzburg voor (Boekspieël 1952:57).

Hierdie werk is 'n Bybelse woordeboek, wat die tersake Skrifverwysings aangee en as sodanig ' $n$ handige bron vir die voorbereiding van preke en oordenkings moes wees. Die direkte getuienis uit die dagboek van Erasmus Smit toon onteenseglik aan dat hierdie werk wel op die Trekpad gebruik is. Dit word deur Pretorius (1988:175) en Carstens en Grobbelaar (1988:148) bevestig.

In Trommius (1750 I:574 (kol.2)) word die onderwerp van geloftes uitvoerig deur die Skriftuurlike verwysings daarna gedek. Trommius behandel die verwysing na geloftes, die beloof van geloftes, die betaal van geloftes en die doen van geloftes. Die verdeling van die Skrifturlike verwysings na geloftes wat Trommius in sy konkordansie maak, naamlik geloftes (dit wil sê naamwoord), die beloof van geloftes, die betaal van geloftes en doen van geloftes, hang waarskynlik saam met die verbondsteologie waarbinne 'n gelofte 'n antwoord op die verbondsbeloftes, "'n vorm van toewyding" is (Pont 1988:38) en voorts om die aandag op die verantwoordelikhede met betrekking tot die aflê van 'n gelofte te vestig. 


\section{DIE AARD EN STRUKTUUR VAN DIE VOORTREKKER- GELOFTE VAN 1838 BINNE DIE TEOLOGIESE KONTEKS VAN DIE NADERE REFORMASIE}

Wanneer op die inhoud van die Gelofte van 1838 gelet word, blyk dit dat, ten spyte van verskillende tekste en weergawes, dit tog 'n kern van ooreenstemming vertoon. Die vernaamste bronne wat by die bepaling van die inhoud van die Gelofte ter sprake kom, is die weergawe van Jan Bantjes (Duvenage 1988 III:147) en die weergawes van H J Hofstede, De Geschiedenis van den Oranje-Vrijstaat (1876:58); sy weergawe van die voorstel van die Gelofte aan die drie gemeentes (1876: 45); die inhoud van die Gelofte volgens Cachet (1882:197) en die bewoording daarvan deur Gerdener (1919:51).

Alhoewel die verloop van die gebeure wat op die aflegging van die Gelofte deur Hofstede (1876:58) en andere beskryf word, is die besonderhede van die beskrywings nie in soveel besondethede vervat soos dié van J D Kestell en N Hofemyr (1898?:193-195) se rekonstruksie van die gebeure nie. Die belangwekkende in laasgenoemde mededelings is geleě in die feit dat Kestell self nog kontak met die Natalse Voortrekkers, byvoorbeeld die Voortrekkerleraar Erasmus Smit en sy vrou Susanna, in Pietermaritzburg gehad en besondere moeite gedoen het om die Voortrekkergeskiedenis te boek te stel (bv in sy werk Die Voortrekkers (1920) en 'n artikel oor Voortrekkers wat hy geken het in Die Huisgenoot van Desember 1938:147, 149). Die rekonstruksie van Kestell en Hofmeyr van die gebeure aanleidend tot die Gelofte, bied waardevolle perspektiewe om die Gelofte in die regte perspektief te plaas en die gebeure tot die aanloop daarvan beter te interpreteer. Volgens hiendie rekonstruksie kan die volgende belangrike aspekte in die aanloop tot die aflegging van die Gelofte onderskei word: (1) die trek van die Voortrekkerkommando teen die mag van Dingaan vanaf die $28^{\circ}$ November 1838 is gekenmerk deur die ernstige inslag van die godsdienstige byeenkomste wat elke aand in die laer gehou is; (2) die eerste Sondag tydens die uittog is 'n kragtige preek deur Sarel Cilliers oor die oorloe van die Israeliete, soos in die boek Josua beskryf, gehou; (3) mettertyd ontstaan die vraag spontaan onder die burgers of dit nie goed sou wees indien die kommando 'n gelofte sou aflê volgens die voorbeeld van Jefta, wat hy afgelê het voordat hy teen die Ammoniete opgetrek het nie; (4) die gedagte kom mettertyd tot rypheid dat indien die vyand verslaan sou word, 'n huis van gebed gebou en die dag van 
orwinning elke jaar as 'n dankdag gevier moes word; (5) die eersvolgende Sondag kon selfs Cilliers nie die belangwekkende saak van die moontlike aflegging van 'n gelofte onaangeroer laat nie, omdat die gemoedere "waren ook al tot berstens toe vol er van"; (6) nadat hy uit Josua 1 gepreek het, het hy die vraag vir die eerste keer aan die burgers gestel of hulle 'n gelofte wou aflê en toe - met verwysing na die gelofte van Jefta daarop gewys dat geloftes groot offers eis, sodat Jefta selfs sy enigste dogter moes opoffer: "Ik bid u, broeders, speelt niet met geloften. Laat af van zulke heilige zaken. God laat zich niet bespotten. De Heer onze God is een ijverig God!"; (7) nadat hy aan die burgers geleentheid gegee het om die implikasies daarvan te oordink, het Cilliers die volgende woorde geuiter: "Broeders! Landgenooten! Wij staan in dezen plechtigen stond voor den heiligen God van hemel en aarde, om Hem eene gelofte te doen, dat, indien Hij met ons zijn zal en onzen vijand aan ons zal overleveren, wij den dag der overwinning als een Sabbat tot Zijne eer zullen vieren; en dat wij onze kinderen zullen vermanen in-deze te blijven volharden, tot eene gedachtenis zelfs aan ons verste nageslacht. Gode zullen alzoo de eer en de heerlijkheid voor de overwinning toegeschreven worden, welke wij door Zijne kracht over den vijand behalen zullen." (8) Cilliers het die burgers vervolgens gevra of daar enige van die teenwoordiges was wat van gevoel was dat hulle nie aan die "plechtige en vreeselijke gelofte mag deelnemen? Indien de zoodanige hier tegenwoordig zij, laat hem zich van deze plaats verwijderen"; (9) nadat Cilliers geleentheid gegee het vir onwillige burgers om hulle van die byeenkoms te verwyder, het hy namens die burgers tot God genader: "Ik zie, dat gij allen éen van hart en éen van zin zijt. Als uw aller tolk zal ik tot God spreken"; (10) daarna het hy gevra dat die teenwoordiges saam bid, waarop hy sy hande na die hemel uitgestrek en namens almal teenwoordig die Gelofte aan God gedoen het, "in een gebed, zooals ik nooit een van menschenlippen heb hooren vloeien" (ons kursivering); (11) waarna die verrigtinge deur samesang afgesluit is (Kestell \& Hofmeyr 1998:193-195).

Die belangwekkende uit hierdie rekonstruksie is onder andere dat: (a) al die gesaghebbende optekeninge van die aflegging van en die omstandighede omringend daarvan sinvol binne die bogemelde fasette tuisgebring kan word; (b) die erns van die aflegging en die verantwoordelike hantering daarvan deur Cilliers duidelik blyk; (c) die aflegging van die Gelofte in die vorm van 'n gebed geskied het - in ooreenstemming met 
die benadering wat die "oude schrijvers" (hieronder bespreek) daarop nahou; (d) die aflegging van die Gelofte uit twee belangrike fasette bestaan, naamlik eerstens die voorlees van die woorde van Cilliers aan die burgers in die vorm van 'n onderlinge onderneming en tweedens die aflegging van die Gelofte teenoor God in die vorm van 'n gebed en, $(f)$ alhoewel ons nie vandag oor die presiese bewoording van die gebed waarin die Gelofte vervat was, beskik nie, die rekonstruksie van Kestell en Hofmeyr - saamgelees met die beskikbare weergawes van die woorde van Cilliers - duidelik aandui dat dieselfde ondernemings wat Cilliers aan die burgers voorgehou het, ook in die Gelofte (vervat in die gebed) beliggaam was.

Die gemeenskaplike elemente van hierdie Gelofte kan soos volg saamgevat word: Die Voortrekkergelofte van 1838 is 'n kollektiewe en konkrete verbintenis aan en op grond van die geloof in die Drie-enige, heilige, soewereine en almagtige God, uitgaande van 'n persoonlike verbondsverhouding wat die verbondsvolk tot verantwoordelike en aktiewe geloofsdade beweeg, om in die lig van God se gebooie die eer van God te soek en aktief te bevorder.

\subsection{Die Voortrekkergelofte is 'n kollektiewe verbintenis}

In die voorstel van die Gelofte aan die drie gemeentes, volgens Hofstede (1876: 45), was die gedagte "(d)at allen biddende" in gees en waarheid aan God om die oorwinning. Die oproep volgens Hofstede se weergawe was soos volg: "Mijne Broeders en medelandgenooten, hier staan wij thans ...." en dit wat daarna volg. Cachet (1882:197) se weergawe stem feitlik woordeliks met dié van Hofstede coreen, tot dié mate dat G D J Duvenage (1988:188) kan opmerk dat hy ook Hofstede se teks gevolg het, behalwe waar hy enkele kleiner taalkundige veranderinge aangebring het. Op sy beurt het ook Gerdener (1919:51) vir Hofstede gevolg met enkele taalkundige veranderinge, weglatings en byvoegings en dit soos volg verduidelik: "Die teks van hierdie gelofte kan niemand natuurlik vandag presies weergee nie. Die woorde wat Cilliers self op sy sterfbed neergeskrijwe het, vind die leser in sij Joernaal (Aanhangsel I). Hierbowe het ons daardie woorde nagenoeg corgeneem, met 'n paar wysiginge wat ons nodig beskouw het, veral die toevoeging van die sin omtrent die oprigting van 'n Tempel, wat later op Maritzburg geskied is. Dit was ongetwijfeld deel van die gelofte, maar is deur Cilliers in sij 
sterfbedverklaring uitgelaat. Bowestaande teks is, sover ons kan oordeel, so na aan die oorspronklike as molik."

In à Brakel (1739 II:508) kom die gedagte dat die gelofte deur die verbond gekonstitueer word, duidelik na vore. Die verbond van genade, waarvan die doop 'n teken is, skep die moontlikheid van 'n gelofte waardeur die gelowiges hulself tot gehoorsaaamheid in God verbind: “Als yemant in het verbondt der genade ingaet/dan verbindt hy die dog verbonden was/met goedtkeuringe/genoegen/ende gewilligheyt/hem selven om eeuwig des Heeren te zijn/en om door den Geest Godts na zynen wille bestiert te worden; hy geeft hem de handt/en hy herhaelt al dikwijls de verbintenisse met al zijn herte." Die genadeverbond, met die teken van die doop, maak dit moontlik dat gelowiges nie net kollektief 'n gelofte kan maak nie, maar dat ook die nageslagte gebind kan word, omdat die gelowiges op grond van die genadeverbond in 'n besondere verhouding met God opgeneem is (Pont 1988:48). Dit moet dus duidelik gestel word dat die Voortrekkers die nageslag aan die Gelofte wou bind, nie soseer op grond van die Gelofte self nie, maar op grond van die verbond wat kragtens sy oprigting deur God die nageslag betrek. Nakoming van die Gelofte deur die nageslag is dus ten diepste diens aan God kragtens die verbond waardeur God ook die God van die kinders (nageslag). is. H C J Flemming (1971:15) gebruik selfs die term "gelofteverbond" om die aard van die Gelofte te beskryf, terwyl A A Venter (1971:10-11), met verwysing na die nakoming van die Gelofte skryf dat die erfgename van die verbond "openbaar as vrug hiervan 'n vroom, opregte en godvresende lewenswandel.” D P M Beukes (1971:9), nadat hy die vraag gestel het of è̀n geslag van 'n volk die reg en bevoegdheid het om die nageslag met 'n gelofte te verbind, kom dan tot die gevolgtrekking dat "(o)ns voorsate het as Calvinistiesverankerde gelowiges vanuit die verbondsbeskouing geglo dat hul nageslag net soos hulle die beskikkinge van God in die lewe van 'n volk sal erken en dus altyd saam aan Hom die dank sal wil bring vir wonderlike uitredding uit die donkere nood van dreigende uitwissing." (Kursivering deur die outeurs). Hy kom dan tot die gevolgtrekking dat dit vandag ons voorreg en roeping is om te toon dat ons die vertroue wat ons Voortrekkerouers in ons gestel het, waardig is.

In die bekende leksikon van die eerste helfte van die 18de eeu deur Marthinus Koning (1662-1732), Lexikon Hieroglyphicum Sacro-Profanum, of Woordboek van 
Gewyde en Ongewyde Voor- en Zinnebeelden, Waarin Personen, Daden, Tyden, Plaatsen, Dieren, Boomen, Planten, Kruiden, Visschen ... (1722), wys die skrywer daarop dat geloftes en die opheffing daarvan deur die vader as verbondshoof gedoen mag word (1722 I:157). Ook hier, soos by ander skrywers binne die konteks van die Nadere Reformasie, word die verbondsgrondslag van geloftes teenoor die Here afgelê, gehandhaaf. Alhoewel vermelding van Koning se werke nie uitdruklik onder die verwysings na die literatuur van die Voortrekkers voorkom nie, is sy werke wel in die vroee Kaapse tydperk gelees (W J van $\mathrm{Zijl}$ 1991:253). Wat beloftes en geloftes betref, is sy standpunte volledig in ooreenstemming met dié van ander "oude schrijvers" wat deur die Voortrekkers gelees is en as sodanig kan sy werke as nuttige "kontrolebron" gebruik word. Tereg skryf Van Zijl (1991:29) dat die Von Dessin-versameling (waarin ook 'n werk van Koning voorkom) as verteenwoodigend van die boekery van die predikante uit die $18^{\circ}$ eeu beskou kan word en aanduidings gee van van die teologiese aksente wat intertyd onder die Kaapse predikante gangbaar was, wat dus beteken dat die kerklike bediening van die Kaapse grensboere waarskynlik ook hierdie aksente met betrekking tọt die verbond en geloftes gedra het, reeds meer as 'n halwe eeu voordat die Trekkers die Kaapkolonie verlaat het.

Met verwysing na Psalm 76:12, 13: "Doen geloftes en betaal dié aan die Here julle God! Laat almal wat rondom Hom is, geskenke bring aan die Vreeslike, wat die trots van die vorste wegsny, vreeslik is vir die konings van die aarde" (1953-vertaling), handhaaf Abraham Hellenbroek (1734, II: 421-422) dat die persone wat hier aangespreek word, almal is wat rondom die Here is. Benewens die engele en die priesters wat gesê sou kon word rondom die Here is, word ook die hele volk Israel hier bedoel met 'n sinspeling op die laerplekke wat hulle in die woestyn gehad het; omdat hulle ook in Kanaăn rondom Jerusalem vergader was, dus rondom die heiligdom van die Here; omdat hulle ook op 'n besondere wyse hulle van die ander volkere onderskei het en as 't ware rondom die Here was (1734, II: 422). Dit bied die geleentheid vir die sluiting ook van volksgeloftes deur diegene wat op 'n besondere wyse rondom die Here is, vanwee hul besondere roeping, diens van God ensomeer. In sy Euangelische Jesaja (1729, II:258), by 'n ontleding van die teks van Jesaja 19:21, fokus Hellenbroek op die gedagte dat benewens om God te ken en dit voldoende verpligtend werk om God te dien, die gelowiges hulself nogtans deur 'n besondere gelofte kan verbind om, soos die volk Israel, 
hulle sterker tot diens aan die Here te verbind: "Daar toe hebben ook al die particuliere verbonden gedient, die en Moses, en vroome Koningen van Juda, en Esra by verscheide gelegentheden/met het volk gemaakt hebben/om haar buiten een algemeene/verpligting/ nog te nader te verbinden tot des Heeren dienst." In die Ou Testament, volgens Hellenbroek, is die idee van volksverbonde dus nie vreemd nie.

Die verband tussen die genadeverbond en geloftes kom by Johannes D'Outrein, Het gouden kleinoot van de leere der waarheid (1752:585) nog sterker na vore. Onder Sondag XXXVII, vraag 101, onder die hoof "De Geloften", met betrekking tot die vraag of die oprigting van 'n verbond met God as 'n eed aangemerk kan word, verklaar D'Outrein, met verwysing na 2 Kronieke 15:12-15, soos volg: "Dus staat 'er van 't Verbondt des gantschen volks. 2 Chron. XV:12-15. Ende zy traden in een Verbondt, dat zy den Heere den God haarer Vaderen zoeken zouden.- Ende zy zwoeren den Heere met luider stemme, ende met gejuich, desgelyken met trompetten, ende met bazuinen. Ende gantsch Juda was verblydt over dezen eedt." Vervolgens handhaaf D'Outrein (1752:585) dat die oprigting van die genadeverbond deur "een iegelyke ziele" as so 'n eed aangemerk kan word. Van die verband van so 'n eed met die genadeverbond, skryf D'Outrein (1752:585): "En dewyle de toestemming aan 't Genaaden verbondt by ' $t$ gebruik der Sacramenten vernieuwt wordt, zoo geschiedt ook daar by een nieuwe eedt tot God." Volgens D'Outrein vind die kollektiewe gelofte (as eed) sy basis in die genadeverbond. In hierdie verband is dit ook belangrik om na die werk van Smytegelt te verwys. Alhoewel hy nie spesifiek met geloftes as sodanig handel nie, kom aspekte van ondernemings teenoor God gemaak, wel ter sprake.

In sy uiteensetting van die aard en voorwaardes van geloftes, beklemtoon Foeke Sjoerd, Kort Vertoog van den staat en de geschiedenissen der Kerke, van de schepping tot op Christus (1761: 405-406) dat geloftes deur mense gedoen kan word aangaande hulself of omtrent andere. Dit kan selfs geskied deur ouers omtrent hul kinders, deur hulle byvoorbeeld aan die diens van die Here te wy, byvoorbeeld die wyding van Hanna van haar seun Samuel. Die sluiting van 'n kollektiewe gelofte word dus deur en op grond van die genadeverbond mootlik gemaak.

Die oprigting van 'n verbond deur 'n volk met God, is nie slegs 'n handeling tussen elke individu en God nie, maar ook tussen elke individu onderling en kollektief 
met God, wat verklaar waarom die aflegging van die Gelofte gepaard gegaan het met die geleentheid dat elke burger homself vrywilliglik van die aflegging kon verwyder, soos hieronder verder aangedui sal word. Bernardus Smytegelt (1780:564) stel die gedagte van eedaflegging teenoor die medemens soos volg: "Den Eed mag geschieden in ' $t$ aangaan van verbonden, tusschen particuliere menschen/als tusschen man en vrouwe; de eene vriend mag ' $t$ aan den anderen doen: Potentaten aan Potentaten, Volkeren aan Volkeren. Ook mag den Eed geschieden in 't Verbondmaken met God: in den Doop, in 't Avondmaal, na een ziekbed/alsiemand overtuigd word/als hy krygt door te breken/na dat iemand genade in Gods oogen gevonden heeft." Waar C J Mans (1967:109-110) 'n onderskeid tussen die Gelofte van 1838 en die hernuwing daarvan by Paardekraal in 1880 tref op grond van die feit dat in die eerste geval 'n belofte aan God gedoen is, terwyl in die tweede geval dit in "de tegenwoordigheid van God" afgelê is, en dat die tweede dus 'n "verbond met mekaar wat in teenwoordigheid van God gesluit is en met 'n eed in sy Naam bevestig is" en dat dus afgelei word dat die twee dus "duidelik nie op dieselfde vlak" lê nie, kan nie onderskryf word nie. Implisiet in die Gelofte is die element van wedersydse verbintenis tot trou aan mekaar opgesluit, soos dit die geval was met die sluiting van die covenant in die Skotse tradisie (Pont 1988: 40).

\subsection{Dit is ' $n$ konkrete verbintenis}

Die trant van die Gelofte is van 'n konkrete aard, naamlik om spesifiek die oorwinning in die hand van die Trekker-kommando te gee. In die voorstel van die Gelofte aan die drie gemeentes, volgens Hofstede (1876:45) word die spesifieke saak waarom dit gaan beskryf as "eene volkome corwinning op hunne vijand". Volgens Hofstede (1876:58) se weergawe van die Gelofte word dit geformuleer "als hij met zijne bescherming, met ons zal wezen, en onze vijand in onze handen, zal geven dat wij hem oorwinnen." Die teks van Cachet (1882:197) en Gerdener (1919:51) stem hiermee wesenlik ooreen. Wat die belofte teenoor God spesifiek betref, lui die voorstel aan die drie gemeentes dat indien God die oorwinning op hul gebed sou gee, dat "zij dien dag jaarlijks als een feestdag ter eere van God doorbrengen en een tempel ter zijne eer stichten zoude, waar het Hem zoude behagen, opdat het nageslacht nooit zoude vergeten, hoe de Heer hun Vaderen uit zoo grooten nood geholpen had" (Hofstede 1876:45; kyk ook Voigt 1899, II:91)). Volgens Hofstede (1876:58) se teks, is aan die Here beloof “dat wij die dag, en de datum, 
elk jaar als een verjaarsdag, en een dankdag zoo als een Sabbath, en zijne eere dienen zal doorbrengen en dat wij het ook aan onze kinderen zal zeggen, dat zij met ons er in moeten deelen, tot gedachtenis, ook voor ons opkomende geslagten". Gerdener (1919:51) het Hofstede gevolg, maar 'n sin bygevoeg “en dat wij een tempel tot zijn eer stichten zal, waar het Hem zou behagen .... "In die geval van Cachet (1882:197) is Hofstede se teks ook gevolg, maar "als een verjaarsdag" voor "als een dankdag" is weggelaat. Die belangrike is egter dat die konkreetheid van die Trekkers se onderneming uit al die beskikbare weergawes van die Gelofte blyk.

Wilhelmus à Brakel (1739, II:509) gebruik die term "particuliere" om die konkrete aard van geloftes te beskryf: "De gelofte moet van een particuliere sake zijn/die wy in hare natuure en omstandigheden kennen/en waer van wy versekert zijn dat wy ze mogen en konnen doen." Die doen van so 'n gelofte kan nie maar net 'n vae en algemene saak wees nie. Hierin, verklaar à Brakel (1739, II:509), dat Jefta homself besondig het deur 'n algemene belofte te maak. Die gedagte dat slegs iets wat binne die vermoz van die persoon of persone is onderneem mag word, het reeds by De Bres (1562: 435) na vore gekom: "Wanneer ons 'n gelofte doen, moet ons deeglik ondersoek of dit wat ons wil beloof in ons mag is al dan nie ... Indien die priesters en monnike van die pousdom hieroor goed oor nagedink het, sou hulle nie onderneem het om kuisheid te belowe nie" (vertaling van die outeurs AWGR en ER).

Hellenbroek (1734, II:423) meld dat die heilige geloftes van die volk van God, somtyds geskied tot erkenning van dankbaarheid vir weldade en verlossinge bewys; meestal in nood en gevaar gedoen om verlos te word; hetsy van publieke of algemene nood, hetsy om dit vry te loop of om daar uit te kom (met verwysing na Ps 66:16); hetsy onder besondere nood of ligaamlike "ongevallen", ter aansporing van "verwakkering in Godzaligheid." Vervolgens omskryf Hellenbroek (1734, II: 423) geloftes dan as "heilige en Godsdienstige Verbintenissen, waar door men bedaardelyk en gewilliglyk aan den Heere belooft iets te zullen doen dat of geboden/of ten minsten geoorloft en middelmatig is/en dat tot eere van God/tot uitwerking van onze zaligheid/en byzonder tot betuiging van Dankbaarheid strekken kan." Elders (1729, II:258) skryf Hellenbroek dat die diens van God, op sigself so nodig en betaamlik, nogtans deur "particuliere obligatie", deur mense gemaak, "zonderling worden opgewakkert". Vervolgens noem hy die gedenksteen deur Josua opgerig en die geloftes deur Moses en die vroom konings afgelê. 
D'Outrein (1752:585-586) tref 'n onderskeid tussen seremoniële en evangeliese geloftes. Die seremoniěle geloftes raak die gelowige nie meer nie, maar wel die evangeliese geloftes. Die pligte deur hierdie geloftes opgelê word deur D'Outrein (1752:586) soos volg beskryf: "Wanneer zich iemandt door den drift des Heiligen Geestes aan God verbindt, om door 't afleggen van zeekere plichten, den zelven dies te krachtiger voor ontfangene groote weldaaden dankbaar te zyn, of in gewichtige omstandigheden voor ' $t$ aanstaande tot zyne hulpe Hem te bewegen. Dus was het met de gelofte van Jacob gestelt. Gen. XXVIII:20-22."

\subsection{Dit is ' $n$ verbintenis aan en op grond van die geloof in die Drie-enige, Soewe- reine en Almagtige God}

Die voorstel van die Gelofte aan die drie gemeentes, volgens Hofstede (1876: 45), lui "(d)at allen biddende in geest en in waarheid aan God zoude vragen om een volkome oorwinning ..." Uit die weergawes van Hofstede (1876:58) spreek die diepe Godsbesef van die Voortrekkers waar hul voor die aangesig van God deur Sarel Cilliers in die aflegging van die Gelofte voorgegaan is: "Mijne Broeders en mede-landgenooten, hier staan wij thans op een Ogenblik voor een heilige God, van hemel en aarde, om een belofte aan hem te beloven ...." Sowel die weergawes van Cachet (1882:197) en Gerdener (1919:51) stem grootliks hiermee ooreen. Die mededelings van Jan Bantjes (Duvenage 1988, III:147) kom ook hiermee ooreen vir sover hy meedeel dat Pretorius die gemeentes gevra het om "aan den Almagtigen eene gelofte doen wilde ..." Die Voortrekkerherinneringe van Louis Jacobus Nel (1939:73) vertel eksplisiet dat die Gelofte soos 'n gebed afgelê is: "Maar op aandrang van die Kommandant (Pretorius) en met goedkeuring van die hele kommando het Sarel Cilliers op die kanonwa gaan staan en met uitgestrekte hande, soos 'n gebed die gelofte gedoen." Die beskrywing van J.D. Kestell en N Hofmeyr (1889?:193-195) bevat 'n uitgebreide rekonstruksie van die aflegging van die Gelofte deur Cilliers. Nadat Cilliers geleentheid gegee het dat burgers wat hul nie met die aflegging van die Gelofte kon vereenselwig nie, die samekoms kon verlaat, het hy hulle plegtig aangespreek: "Ik zie, dat gij allen éen van hart en éen van zin zijt. Als uw aller tolk zal ik tot God spreken. Laat ons bidden." Nadat Cilliers sy hande na die hemel uitgesteek het, het hy, volgens die skrywers, namens almal teenwoordig 'n gebed gedoen, waarin die Gelofte vervat was: 
Toen strekte hij zijne handen uit naar den hemel en deed namens allen daar vergadert, de groote gelofte aan God, in een gebed, zooals ik er nooit een van menschenlippen heb hooren vloeien. Zelfs te Vechtkop, toen de Matabelen ons omringden als bijen, greep zijn gebed mij niet zoo aan als thans. Het was mij of er een Profeet uit het oude Israel in ons midden stond: ik wist niet waar ik was. Als op vleugelen werd ik weggevoerd in een gebied waar tijd noch ruimte gevonden wordt. Van die ure af aan heb ik eerbied voor alle geestelijke ondervindingen mijner medemenschen.

Ook J H Malan (1913:229) beskryf die gebedskarakter van die Gelofte in soortgelyke terme. 'Nàdat Cilliers gepreek het, is die Gelofte deur Cilliers in die vorm van 'n gebed afgelê 'met sij hande naar die hemel uitgebrei, namens en met sij bij hem te'enwoordige landgenote, die gelofte, soals vermeld, in hartgrondige, eenvoudige woorde aan sij Skepper ...."”

Die voorgaande bevinding van die gebedskarakter van die Gelofte word cok deur J M G Storm (1988:59-60) bevestig waar hy, met verwysing na die beskrywing van Bantjes, Pretorius se eie verklaring oor die Gelofte en Cilliers se mededelings in hiendie verband tot die gevolgtrekking kom dat die Gelofte in die vorm van 'n gebed afgelê is en dat dit "dus merkwaardig (is) dat nie een van die historici wat die Gelofte se woorde gerekonstrueer het, rekening gehou het met die feit dat dit in 'n gebed plaasgevind het waarin God direk aangespreek word nie."

Die indruk dat die Voortrekkers die aflegging van die Gelofte in die vorm van 'n gebed gedoen het, word versterk deur die beskrywing van sommige "oude schrijvers" wat die aflegging van geloftes ook as vorme van gebede sien. Martinus Koning (1722, I:159) beskryf die gebedsinslag van geloftes soos volg:

En alhoewel beloft- en gewillige offerhanden, konnen dankofferen genoemt worden, zoo is het egter, dat gewillige offerhanden, wel ontvange weldaden en verpligting aan den Heere vooronderstellen, maar niet altydt dat men in noodt geweest, of daaruit verlost is. Dogh de geloft-offerhanden schynen te slaan op nooden en zwaarigheden, en gedaan te worden om als door gebeden Godts zeegen af te bidden, zyn gunst te verwerfen, en Godt als aan den mensch te verbinden. 
Hy vervolg dat belofte- en vrywillige offers in die algemeen gebring moet word om die seën van God te versoek en "dies zoo veel als een gebedt in het byzonder, ook de geloftofferhande, om voorziene of dadelyke dreigende en drukkende rampen en ongevallen af te bidden; int welken hoofde ... de gewillige en beloofde offerhanden noemt een gebet , om het geene wy gaern badden. ...."

Die aard van die verbintenis wat deur geloftes opgelê word, beskryf à Brakel (1739, II:509) as 'n verbintenis aan God, maar ook die gelofte self geskied teenoor God, dat dit wat hy beloof om te doen of te laat, teenoor God sal doen of laat: "Niet aen Engelen/niet aen verstorvene Heyligen/dat is soo wel Afgoderye/als haer aen te bidden/dewijle de belofte te doen/een werk is van Godtsdienst/ende als men belooft yets aen den armen te geven/dan geschiedt de gelofte niet aen den armen/maer aen Godt/om het aen den armen te geven" (met verwysing na Num 30).

Hellenbroek (1734, II: 423) verklaar van die aard van die verbintenis deur geloftes tot stand gebring, dat dit "heilige en Godsdienstige Verbintenissen" is, waardeur, "men bedaardelyk en gewilliglyk aan den Heere belooft iets te zullen doen dat of geboden/of ten minsten geoorloft en middelmatig is." In De Euangelische Jesaja (1729 II:259) beskryf Hellenbroek die Here as "voorwerp" van godsdienstige geloftes in. veel meer direkte terme, binne die konteks van Jesaja 19:21):

Het voorwerp van haar Gods-dienstige verpligting zou DE HEERE zyn: die zelve Jehova, dien zy kennen, dien zy vervolgens door Geestelyk slagt en spysoffer dienen zouden. Wie kon het ook anders wezen? Haar Egyptische drekgooden hadden zy voortyds op zyn Heydensch hare geloften toegebragt; maar nu hadden zy Jehova leeren kennen, en waren bekeert van de Afgoden tot den levendigen God; het moest, het kost dan ook alleen den Heere zyn/dien zy nu haar geloften zouden toebrengen. Die is ook alleen het voorwerp, niet alleen in " $t$ gemeen van alle Godsdienstige pligten/maar speciaal ook van alle heilige geloften." 
D'Outrein (1752:586) stel as voorwaarde vir die gelding van geloftes dat "(m)en moet de gelofte aan niemandt anders dan aan den Heere doen. Psalm LXXVI:12". Johannes à Marck (1730:745) stel dit onomwonde dat mense geloftes aan God alleen moet doen, met uitsluiting van heiliges en engele, omdat ons ons aan God as die Enige en Alwetende Here kan verbind "en daar de Geloften ooveral tot Got worden gebracht Num. XXX. 2. Psal. LXVI. 13.14. LXXVI. 12. Ens." "Op grond hiervan wys d'Outrein die maak van geloftes aan enige skepsel of persoon af.

In die definisie van Foeke Sjoerds (1761: 405) beskryf hy die voorwerp van geloftes in terme van "zekere Godsdienstige daden, waar door ymant vrywillig zig verpligtte, om zig zelven, of iets anders aan Gode tot zyne eere en dienst, over te geven en toe te heiligen", welke verbintenis deur God as die groot Wetgewer self voorgeskryf word (Deut 23:21-23; Lev 27).

\subsection{Dit gaan uit van 'n persoonlike verbondsverhouding}

Die verbondsaard van die Gelofte spreek deels uit die teologiese tradisie van Bullinger en Ursinus, wat hierbo behandel is. Voorts spreek dit uit die vrywillige aard van die aflegging van die Gelofte op 9 Desember 1838. In sy Joernaal teken Bantjes op dat Andries Pretorius die lede van die kommando meegedeel het dat hulle 'n gelofte aan die Here moes doen indien almal daartoe sou instem (Duvenage 1988 III:147). Ook Hofstede (1876:58) maak daarvan melding dat indien daar onder die manskappe beswaardes teen die aflegging van die gelofte was, hulle die vergadering moes verlaat ("dat die dan van deze plaats, weg moeten gaan"). Cachet (1882:197) stel dit die duidelikste: "Na eerst verzocht te hebben, dat ieder, die zich bezwaard gevoelde, in dit verbond te treden, zich zou verwijderen, breidde Cillier, in naam van al de aanwezigen, zijn handen uit naar den hemel en sloot, als Willem van Oranje weleer, een verbond met den Potentaat der Potentaten (sien ook S P Engelbrecht 1920:22). Dit verbond werd elke avond en elken Zondag, bij de gebruikelijke Godsdienstige bijeekomsten, vernieuwd." In hul rekonstruksie van die aflegging van die Gelofte, maak J D Kestell en N Hofmeyr (1898:194-195) uitdruklik daarvan melding dat Cilliers, nadat hy die woorde van die Gelofte geuiter het, geleentheid gegee dat diegene wat nie aan die aflegging van die Gelofte wou deelneem nie, hulle van die byeenkoms kon verwyder: "Is er iemand hier 
tegenwoordig, die, na de woorden welke ik hem in den Naam des Heeren heb toegesproken, gevoelt dat hij niet met ons aan die plechtige en vreeslijke gelofte mag deelnemen? Indien de zoodanige hier tegenwoordig zij, laat hem zich van deze plaats verwijderen." Nadat die burgers, volgens die skrywers, ter vergadering gebly het, het Cilliers die Trekkers in gebed voorgegaan.

Die vrywillige aard van geloftes staan hier sentraal. Martinus Koning (1722, I:157) stel dit in geen onsekere terme nie: "Die geloften moesten uit een godvrugtig hart, tot een godtsdienstig einde, in middelmatige dingen, ongedwongen gedaan worden; ....."

À Brakel (1739, II:508) beskryf geloftes teen die agtergrond van die verbondsaard daarvan. Hy skryf dat 'n gelofte dieselfde aard het as 'n eed aan God, dat mens Hom sal dien: "Als yemant in het verbondt der genade ingaet/dan verbindt hy die dog verbonden was/met goedtkeuringe/genoegen/ende gewilligheyt/hem selven om eeuwig des Heeren te zijn" en, met verwysing na 2 Kronieke 15:12, 14: "Ende zy traden in een verbondt dat zy den Heere den Godt harer Vaderen soeken souden met haer gansche herte, ende met hare gansche ziele. Ende zy zwoeren den Heere met luyder stemme. Ps. CXIX:106"

Hellenbroek (1734, II: 424) laat die klem by geloftes op die Verbondsgod val. Met verwysing na Psalm 76:12, 13, fokus hy op die feit dat geloftes aan die Verbondsgod gedoen moet word. Omdat hier godsdienstige verpligtinge op die spel is, kan dit slegs teenoor "Den Heer uwen God, Jehovah", die enigste ware God, geskied omdat Hy sy volk by Sinai, deur 'n besondere volksverbond, as besondere eiendom uit al die volkere aangeneem het; tweedens "Haar God, ook in de nadruk van 't Genade-Verbond, in opzicht van die geen die onder haar in een gelovige nadruk Rondom hem waren/en overgegaan in een gelovige Gemeenschap met hem." Omdat geloftes ook 'n soort van gebed is, 'n vorm van eed, wat deur die gelowige aan God geskied; ten slotte "van niemand kunnen zy ook als van den Heere Gekend en Gehoord: ... van niemand als van hem Beantwoord worden: zo zingt Isracls Zanger/De lofzang is in stilheid tot $u, O$ God, in Zion: ende u zal de gelofte betaalt worden, Ps. 65:2."

D'Outrein (1752:585) sien geloftes in verband met die genadeverbond in die lig van Jesaja 45:23 en Jesaja 19:18, 65:16 as uitloper van die genadeverbond in die vorm van 'n nuwe eed, soos "de toestemming aan 't genaaden verbondt by 't gebruik der 
Sacramenten vernieuwt wordt ...." Die bestaan van geloftes kan dus nie van die genadeverbond losgemaak word nie. Geloftes is as 't ware uitlopers van die genadeverbond. Geloftes vertoon dus ook die kenmerke van die verbond.

Die trou van God binne die verbond staan vas, omdat God die voorbeeld van trou deur sy eed aan Homself gesweer het: "God heeft gezwooren by hem zelven, by zyne heerlykheid, by zyne heiligheid. Dan zwoer hy eens by Jacobs heerlykheid, Amos VIII: 7. Dan eens by zyne heiligheid, Ps. LXXXIX:36. .... Hebr. VI:13. zweert God by hem zelven/dewyl hy by niemant, die meerder was, en hadde te zweeren. Hy heeft gezwooren aan den Heere Jezus. Hy heeft gezwooren aan Abraham" (Smytegelt 1780:562).

\subsection{Dit beweeg die verbondsvolk tot verantwoordelike en aktiewe geloofsdade}

Volgens die weergawes van die Gelofte by Hofstede (1876:45, 58); Cachet (1882:197) en Gerdener (1919:51) het die Trekker-kommando belangrike onderneminge gemaak wat die inhoud van die Gelofte uitgemaak het (sien ook Voigt 1899, II: 91). Dit shit in die verwysings na die die jaarlikse hou van 'n dankdag, soos 'n Sabbat; die mededeling van die inhoud van die Gelofte aan die nageslagte; dat die roem en eer van God verheerlik sal word, deur die roem en eer van die oorwinning aan God te gee ensomeer. Die latere verloop van die militêre ontmoeting met die Zoeloes aan die Ngomerivier op 16 Desember 1838 is welbekend. Tot vandag gryp die militêre verloop van die stryd op dié dag die verbeelding van historici en militêre historici aan. Dit is egter hier van meer belang om op die optrede van die Trekker-kommando onmiddelik na afloop van die slag te let. Die deeglike dokumentasie van die gebeure en versameling daarvan deur Duvenage (1988, III:161) bied 'i handige bron van historiese gegewens in hierdie verband.

Nadat almal, na afloop van die slag, in die laer terug was, het Pretorius die kommando lat eet en die burgers toe byeengeroep om God vir die oorwinning te dank. Vogens F P van Gass (Preller 1918:51) het die Trekkers byeengekom en "verenigden wij ons in het midden van het lager tot het opzenden tot God van een dankoffer voor de overwinning, met zijne hulp, op zo 'n overstelpende meerderheid van tot die tijd gerekend een onoverwinbare vijand en de schrik en vrees van allen." Die wesenlike elemente daarvan vind ons op soortgelyke wyse by Hofstede (1876:491); J G Bantjes 
(Duvenage 1988:161) en F Lion Cachet (1882:200-201). By laasgenoemde outeur, sowel as I J Breytenbach se Voortrekkerherinneringe (Duvenage 1988:162) kom die interessante fasset na vore dat by die dankstond na die terugkeer van die kommando, die Gelofte weer eens hernu is: "In de achtermiddag van die Zondag, toen allen weder teruggekeerd waren, en wij gegeten hadden, werden bij elkander geroepen. De Komdt.-genl. vertelde ons dat wij bijeengeroepen waren om voor de Heere 'n belofte af te leggen. S. Cilliers nam ' $t$ woord, en zeide ongeveer, dat wij de belofte de Heeren deden, omdat Hij ons zo genadig uit de hand des vijands had verlost, en dat die dag, 16 Dec 1838, steeds 'n dank-, bede- en herinneringsdag zal wezen van geslacht tot geslacht" (kursivering van Duvenage) (sien ook die Engelse weergawe van Bantjes se Joernaal in Moodie 1888:552-569 op 566).

By die aflegging van 'n volksgelofte, soos ons hier het, kom die element van onderlinge verbondenheid aan mekaar voor die aangesig van God ook sterk na vore. Hierdie onderlinge verbondenheid by 'n plegtige geleentheid, dra sterk elemente van 'n onderlinge eed wat teenoor mede-volksgenote afgelê word. Die feit dat elke burger geleentheid gehad het om blyke van aanvaarding of verwydering van die aflegging van die Gelofte te gee, moet teen die agtergrond van die eedskarakter van die Gelofte gesien word. Hierdie gedagte stel Smytegelt (1780:569) soos volg: "Op die of diergelyke wyze moet ik en gy den Eed aan God gedaan hebben: en dan zal God met den goeden wezen. Weest opregt/conscientieus: zegt; God is myn getuige dat ik niet liege, Rom. IX: I."

Die feit dat die Geloftekerk te Pietermaritzburg deur die Trekkers opgerig is en dat die Gelofte wel die mate van inslag in die Afrikaner se volkslewe gevind het wat dit wel het, getuig tot 'n mindere of meerdere mate van die "verantwoordelike en aktiewe" wyse waarop die Gelofte die volkslewe van die Voortrekkers in beweging gebring het. Veral kom die "offer-"karakter van die Gelofte hier sterk op die voorgrond. Martinus Koning (1722 I:159) verduidelik dit soos volg: "En gelyk deze offerhanden toegezegt, of betragt werden, zoo om zeegen, heil en voorspoet te verwerven, om plaagen en oordeelen af te wenden; in dezelve zynde verlost te worden; om Godt te danken naa de ontfangene weldaden, waar door duidelyk te verstaan wordt gegeven, dat het by den offeraar niet en stonde, nog gestaan hadde, maar aan 's Heeren wille, magt goetheit, getrouwigheit en waarheit, zoo mag men het 'er voor houden, dat gebeeden, dankzeggingen 1 Tim. II. 
vergezelschapt met het leven der vrygekoopten des Heeren, ...." Hierdie mededelings kry besondere betekenis teen die agtergrond van die offers wat gebring moes word om die Geloftekerk onder die verarmde omstandighede waarin die Trekkers verkeer het, op te rig.

Die vrraag tot welke mate die "oude schrijvers" geloftes as vertrekpunte sien wat die volk, wat deur die verbond aan God verbind is, tot aktiewe en verantwoordelike geloofsdade inspireer, kan slegs uit die tekste van hul werke self beantwoord word.

Wilhelmus à Brakel (1739, II:511) maak spesifiek daarvan melding dat geloftes moet geskied by wyse van dankbaarheid of tot bevordering van ons geestelike welstand. Die betaling van so 'n gelofte moet geskied as dankbaarheid jeens God: Offer dank aan God en betaal aan die Allerhoogste u geloftes (Ps 50:14). Waar'n gelofte in nood afgelê is, "men moet bidden om verlossingen/ende in onse beweegredenen ook dese gebruyken/dat wy lust hebben/om den Heere met blijdtschap te dienen/en den Heere te danken/ende te verheerlijken als hy ons soude uytgeholpen hebben/ende dat wy onse danbaerheyt ook souden betoonen/met dit ofte dat te laten/te geven ofte te doen." In die geval waar 'n gelofte tot bevordering van ons geestelike welstand afgelê is, word aktiewe geloofsoptrede vereis om die nakoming van die gelofte en die uitvoering daarvan te verseker (1739, II:511). By sowel die aflegging as die uitvoering van die gelofte moet dit geskied ooreenkomstig die gebod van die Here. By sowel sake wat uit hulself goed is of sake wat middelmatig is, moet dit oor 'n "goeie saak" handel. Sake is op sigself goed "om dat Godt ze geboden heeft; daar toe is men verplicht/en die verplichtinge keurt een geloovige goedt/met toepassinge op hem selven/en herhaelt die verplichtinge dikwijls met al zijn herte ...." (1739, II:509). Selfs middelmatige sake moet geskied "uyt den geloove/op een gebodene maniere/en ter eeren Godts" (1739, II:509). Vir à Brakel kon dit nie 'n vreemde saak gewees het nie, omdat reeds die reformatore dieselfde gedagte gehandhaaf het. Guy de Bres (1522 - 1567) (1562: 435) stel die beginsel soos volg: "Ons moet daarop let dat niemand aan God iets kan beloof, indien hy nie eers in sy gewete verseker is (daarvan) dat dit ' $n$ saak is wat vir God aangenaam is nie .... Want ons weet dat alles wat sonder geloof gedoen is sonde is .... Mense hoef sulke geloftes nie te hou nie." 
Hellenbroek (1734, II:425) beskryf die betaling van geloftes in die volgende terme: "Geloften nu te Betalen is met een woord/dat geen dat men belooft heeft met 'er daad te doen en te volbrengen (Deut 23:21; Num 30:2)". Waar geloftes nie tot betaling daarvan oorgaan nie, "wat is het anders dan God in 't aangezicht te bespotten/zyn Alwetentheid/zyn Almagtigheid/zyn Regtveerdigheid te veragten/zyn genote weldaden te vertreden/zig zelf aan de uiterste trouloosheid en verbondsbreuk schuldig te maken? en daarom wat moet 'er betamelyker zijn; dan als men geloften doet/die ook te Betalen aan den Heere onzen God." In die lig van die woorde van Psalm 76:12, 13: "Laat almal geskenke bring aan die Vreeslike", vertolk Hellenbroek dit so dat dit beteken dat geloftes betaal moet word, welke geskenke insluit offergawes; geestelike geskenke ensomeer (1734, II:426). Hellenbroek (1729, II:265) gee ook 'n duidelike uiteensetting van die aktiewe geloofsgehoorsaamheid wat by die betaling van geloftes na vore moet kom: "Gelofte te betalen, dat is/met een woord/niet anders/dan dat geen met 'er daad te doen, dat men belooft heeft. Door geloften raakt men onder een soort van schuld; om dat zy ons brengt onder een verbintenis: schulden nu is de betaling eigen; en daarom word die spreekwyze ook overgebracht tot die schuld, die men door geloften maakt." Hellenbroek (1729, II:267) betreur die feit dat talle mense hulself nooit tot geloftes teenoor God verbind het nie, terwyl ander mense weer hulself tot sondige geloftes verbind: "Of zoo men geloften doet/zoo zijn het zondige en quade beloften. $O$ ! ja/dat vind men niet dan van al te dikwijls/dat menschen het goede als verloven, en dat zy genoegzaam beloften doen tot zonde: dat zyn geloften/die niet den Heere, maar die den duivel, die de weereld gedaan worden." Daar word dus in die gelofte-beskouing van Hellenbroek tussen geloftes wat "goed" is en uit die geloof gedoen word en dit onderskraag, en valse geloftes wat tot sonde lei en nie geloofsdade tot gevolg het en dit ondersteun nie, onderskei.

D'Outrein (1752:586) behandel die voorwaardes wat op geloftes van toepassing is in ses punte: (1) beloftes wat alleen aan die Here gedoen moet word, moet (2) in nederigheid en onder die besef van onwaardigheid geskied; (3) sulke geloftes moet uit die geloof spnit (Rom 14:23); (4) niks wat sondig, ligvaardig en onbetaamlik is, mag aan die Here beloof word nie (Matt 15:5, 6); (5) mens moet versigtigheid aan die dag le sodat dit nie gebeur soos met Jefta (Rig 11) nie; (6) mens moet niks anders aan God beloof as wat 
reeds onder 'n algemene gebod ingesluit word nie, sodat dit geen eiewillige godsdiens word nie.

À Marck (1730:744) vat die aard van godsdienstige geloftes saam in die volgende beskrywing: "Eene Gotsdienstige Belofte aan Got gedaan van iets te doen of te laaten tot sijne eere en . onse saaligheit." Dit verwys implisiet na die geloofsingesteldheid van die gelowige wat die gelofte teenoor God maak, soos vervolgens gesien kan word.

Wat die aard van geloftes teenoor God gedoen ook mag wees, beklemtoon die "oude schrijvers" deurgaans die feit dat sodanige geloftes spoedig nagekom moet word. Anders as by die aflegging van geloftes - wat met oordeelkundigheid en nie oorhaastig moet geskied nie - moet die nakoming van geloftes nie uitgestel word nie. Martinus Koning (1722, I:158) stel dit soos volg: "De geloften vervingen zaaken en pligten van welke men konde vry zyn en blijven; en vermits men met de zelve te doen uit schielykheit, onbedagtzaamheit, of anders, zig in het vervolg by de bestipte nakomingen vry verleegen en bezwaart vont, zoo hebben de Joodsche meesters geoordeelt, datmen tot het doen niet ligtelyk behoorde te koomen." Koning vervolg dan oor die nakoming daarvan: "Anders dat men zyne geloften aan den Heere gedaan, moest houden, betaalen, en haastiglyk, met gewilligheit des harten, en met vreugde, houde ik te zyn een zaak van ontwyfelbaare waarheit Deut. V Levit. III. Ps. L. 14. Pred. V. 3-4-5."

\subsection{Die Gelofte soek die eer van God en bevorder dit aktief in gehoorsaamheid ann God se gebooje}

In sy Voortrekkerherinneringe het $S$ ' $W$ Burger (Preller 1925:97) vermeld dat Andries Pretorius in sy gesprek met Sarel Cilliers by Danskraal (?) sou gevra het of die Gelofte nie as 'n Sabbat gevier sou word nie: “Hij vroeg aan Charl Cilliers, of sij niet 'n belofte zouden doen aan die Here, dat, indien die Heer hun de overwinning gaf, zij dan die dag zouden voeren als 'n Zondag, jaar na jaar en dat zij het ook aan hun kinderen zouden leren." Tereg toon B L Liebenberg (1977:29-32) aan dat slegs die aankondiging van 'n gelofte by Danskraal gedoen is, maar die Gelofte cers later afgelê is. Die Voortrekker Louis Jacobus Nel (1939:73) maak in sy herinneringe ook melding van hierdie gesprek tussen Pretorius en Cilliers en vertel dat Pretorius vir Cilliers versoek het om aan die Here 'n gelofte te doen dat, as Hy hulle die oorwinning gee, daardie dag jaarliks "godsdienstig 
sou gedenk word, en dat daar kerke en skole in die land sou gebou word." Soos vroeerr aangedui, het die gesprek tussen Cilliers en Pretorius waarskynlik plaasgevind na aanleiding van die feit dat die gedagte aan die aflegging van 'n gelofte spontaan onder die burgers plaasgevind het. In sy Journaal verwys Cilliers na die gesprek met Pretorius en dat hulle ooreengekom het om 'n gelofte te doen "als de Heere ons de overwinning tegen onze vijand zoude geven, dat wij dan die dag als een Sabbath elk jaar zoude heiligen." Volgens Hofstede (1876:196) is daar besluit "dat wij de Here onze God eene belofte pligtig zoude doen, als de Heer met ons zal gaan, en dat Hij ons vijand, in onzen handen zoude geven, dat wij die dag in elk jaar de Heere zoude heiligen, en zoo door brengen als een Sabbathdag." Ook die Voortrekkerherinneringe van Phillippus Jeremias Coetser bevestig hierdie onderneming (Liebenberg 1977:29).

In Bantjes (Duvenage 1988, III:147) se Journaal meld hy weliswaar nie die aspek van die Sabbatdag nie, maar noem wel die feit dat die Gelofte in 'n boek aangeteken moes word en "op dat het ter Eere van God gevierd mag worden." Die getuienis dui sterk daarop dat die gedagte was om die dag van oorwinning tot in die verste nageslagte as ' dag van danksegging, in die vorm van 'n Sabbatdag te vier. Hierdie afleiding word versterk in die lig van die feit dat die oorwinning oor die vyandelike magte op.Sondag 16 Desember 1838 plaasgevind het. Dit moes waarskynlik daartoe bygedrae het om die Sabbatskarakter van die dag te beklemtoon, juis omdat die Trekkergemeenskap sterk nadruk op die instandhouding van die Sabbat gelê het.

Voorts het die Gelofte die belofte van die oprigting van 'n kerk, waar dit God sou behaag, bevat (Gerdener 1919:51; sien ook Pretorius se persoonlike mededelings in 'n brief enkele dae na die slag van Bloedrivier in Liebenberg 1977:32-33). Dit alles dui daarop dat die eer van God vir die Trekker-kommando voorop gestaan het. Dit sou dan die uitloper wees van die oorwinning oor die Zoeloemag, wat nie net vir die verraderlike moord op Retief en sy sewentig man verantwoordelik was nie, maar ook die Trekkers kort daarna op bloeddorstige wyse langs die Moordspruit en Boesmansriviere aangeval en talle mans, vroue en kinders om die lewe gebring het. Hierdie optrede van Dingaan en sy Zoeloemag sou ongetwyfeld vir die Trekkers optrede in stryd met die gebod van God en die Bybelse eise van gehoorsaamheid aan God en liefde teenoor die naaste gewees het. Op grond hiervan sou die veldtog teen Dingaan dus gesien moes word as die herstelling 
van die eer van God en die vergelding van die onskuldige bloed van die slagoffers van die Zoeloe-aanvalle.

Die grond hiervan, sou die Trekkers ook ongetwyfeld uit die teologiese werke deur hulle gebruik kon kry. À Brakel (1739, II:508) verwys in sy omskrywing van geloftes na die feit dat dit moet handel oor 'n saak wat as sodanig goed is: "Een gelofte is een verbintenisse aen Godt om een particuliere goede zake, die in onse macht is, uyt vrye wille te doen ofte laten tot dankbaerheyt, ofte tot bevorderinge van onsen geestelyken welstandt." Voortspruitend hieruit verklaar à Brakel (1739, II:509) dat sommige sake op sigself goed is omdat God dit beveel; daartoe is mens verplig "en die verplichtinge keurt een gloovige goedt/met toepassinge op hem selven/en herhaelt die verplichtinge dikwijls met al zijn herte: maer sommige saken zijn in hare natuure middelmatig/en buyten het gebruyk is het den mensche vry om het te doen of te laten ...."

Hellenbroek (1734, II: 423) noem spesifiek die doel met geloftes om die eer van God te soek in sy omskrywing daarvan: "zo zyn dan Geloften, heilige en Godsdienstige Verbintenissen, waar door men bedaardelyk en gewilliglyk aan den Heere belooft iets te zullen doen dat of geboden/of ten minsten geoorloft en middelmatig is/en dat tot eere van God/tot uitwerking van onze zaligheid/en byzonder tot betuiging van Dankbaarheid strekken kan." Die verwysing in Psalm 76:12, 13 na die bring van geskenke, vertolk Hellenbroek so dat dit onder andere die betekenis het van bewys van respek, eerbied en onderwerping aan God (1734, II;427). Met 'n beroep op die burgerlike owerheid laat Hellenbroek (1734, II:435) geen twyfel oor die strekwydte van 'n publieke gelofte om die eer van God te handhaaf en die wil van God te doen nie: "dat gy al het uwe zult toe brengen tot een publike Reformatie/om alle morgen alle Goddelozen des Lands te verdelgen/en uit de Stad des Heere Alle werkers der ongeregtigheid uit te roejen; om te waken tegen afgoderyen/tegen vloeken en zweren/tegen ' $t$ schenden van des Heere dag/tegen hoereryen/en alle roepende zonden in het Land; om alle Godsdienstigheid en Godzaligheid te queken; om al u magt voor den Heere/voor zyn Kerk/en voor de Waarheid te gebruiken; en al $\mathbf{u}$ heerlykheid in Jezus koninkryk in te brengen/dat gy het Gerigte in alles altyd den Heere houden zult .... dat gy in u Vergader-plaatsen altyd den God der Goden/door en voor wien gy regeert/in't oog zult houden; en een tedere conscientie altyd de rigtsnoer van al $u$ raadslagen zal zyn; dat alle particuliere belangens 
voor de gemene Eendragt, daar wy nu alleen door bestaan kunnen/zullen worden opgeoffert; en dat de welstand van Staat, en Kerk, alleen u grote oogwit zyn zal."

Bykomend by die ses voorwaardes vir geloftes hierbo genoem, voeg D'Outrein (1752:586) by dat die mens verplig is om dit wat God gebied te hou; voorts ook dat mens "geen ander doelwit als Gods eere in zulke geloften hebben. Prov. III:9,10."

Oor die oogmerk van geloftes om die eer van God te bevorder is à Marck (1730: 747) baie eksplisiet: "Het Oogemerk van alle onse Geloften moet zijn de Eere Gots, en Onse daar toe leidende Saaligheit, welke twee dingen men niet t'eenemaal van malkanderen scheiden mach; soo nochtans dat alle inbeeldinge van de Saaligheit te Verdienen als strijdich teegen de Eere Gots verre geweert zij."

Foeke Sjoerds (1761 I: 405) sluit ook by die gedagte van die bevordering van die eer van God aan: "Geloften; zynde zekere Godsdienstige daden, waar door ymant vrywillig zig verpligtte, om zig zelven, of iets anders aan Gode tot zyn eere en dienst, over te geven en toe te heiligen, behoorden mede tot den ingestelden Godsdienst van Israël, en waren dien aangaande verscheide bepalingen van den groten Wetgever gemaakt. Zie Deutr. 23:21-23. Lev. 27".

Waar Bernardus Smytegelt (1780:560) met die ede handel word dieselfde gedagte beklemtoon. In 'n eed is 'n gebed opgesluit; “en zoo heeft den Eed iet met het bidden eigen. ..... Weest niet te snel met uwen monde. Ziet dan en let op: laat uw woord niet onaandagtig zijn." Hierby sluit Smytegelt die gedagte van die bevordering van die eer van God aan: "Gy zult in den Eed binden/dat God geëerd word wegens eenige groote volmaaktheden. Daar word God geěerd, 1. In zijne alwetenheid. 2. In zijne alomtegenwoordigheid. 3. In zijne almagtigheid. 4. In zijne waarheid. 5. In zijne regtvaerdigheid. God word 'er geẻerd in zijne alwetenheid. ..... Men eerd God dat hy "t verborgene kend daar geen mensch agter komen kan." In die eed word God, volgens Smytegelt (1780:560), in Sy alomteenwoordigheid geěer, omdat God "omringt my in myn nederzitten, en in myn opstaan, Ps. CXXXIX ; 2, 3)". Die parallel tussen die aflegging van 'n eed en die maak van 'n gelofte blyk duidelik uit die inhoud van die eed volgens Smytegelt (1780:561):

Wat zeid nu zoo cen als hy zweerd met de woorden/zoo waarlyk helpe my God Almagtig? Hy wil dit zeggen/Heere ! ik bidde U/toond uwe alweetenheid, uwe 
alomtegenwoordigheid, uwe heiligheid, uwe regtvaerdigheid, in my exemplaar te straffen/indien ik liege/tydelik en eeuwig/in ziel en lichaam: zoo ik liege/straft my dan voor ' $t$ oog van de geheele waereld/tot een blyk/dat ik valschelyk gezwooren hebbe; maar indien ik de waarheid spreeke/geeft dan van een blyk/dat gy zulk een God zyt in my te zegenen voor de geheele waereld.

Vir sover 'n gelofte die element van 'n onderneming teenoor God bevat, is dit wat Smytegelt hier van 'n eed en die bevordering van die eer van God sê, ook op geloftes van toepassing.

\section{GEVOLGTREKKING}

Die ondersoek na die teologiese agtergronde van die Voortrekkergelofte (1838) bring belangrike perspektiewe met betrekking tot die bronne wat ' $n$ invloed op die totstandkoming van die Gelofte gehad het en die betekenis daarvan aan die lig:

- Die waardevolle aanvoringswerk wat deur A D Pont in verband met die nasporing van die teologiese agtergronde van die Gelofte gedoen is, beklemtoon onteenseglik die feit dat dit by uitstek uit die bronne van die Nadere Reformasie voortgespruit het.

- Die verstaan van die teologiese agtergrond van die Gelofte gaan tot 'n groot hoogte op die werk van à Brakel terug. Dit was egter nie die enigste werk wat met geloftes handel nie en die bestek van die Gelofte is ook nie ekslusief uit à Brakel te verstaan nie.

- Verskeie ander outeurs van die Nadere Reformasie is in die navorsing geidentifiseer wat ook op bepaalde punte van die inhoud daarvan 'n bydrae gelewer het.

- 'n Analise van die historiese en teologiese bronne waaruit die inhoud van die Gelofte bepaal is, stel ons in staat om 'n omskrywing van die Gelofte te gee.

- Verdere navorsing oor die betekenis van die bydraes van die verskillende outeurs tot die inhoud en handhawing van die Gelofte is wesenlik noodsaaklik.

- Dit is veral die noue verband tussen die verbondsteologie en die Gelofte wat verdere ondersoek verdien; veral met betrekking tot die staatkundige betekenis 
daarvan en die implikasies vir die latere totstandkoming van die Voortrekkerrepubliek in Natalia en die verhouding tussen kerk en staat wat daaruit voortgespruit het.

- Dit moet as kritiese vraag gestel word of die bestaande praktyk van die herbevestiging van die Gelofte op 16 Desember elke jaar by Geloftefeesbyeenkomste histories en teologies verantwoordbaar is vir sover die onderlinge onderneming van die Voortrekkers teenoor mekaar herhaal word, sonder dat die bevestiging daarvan by wyse van 'n gebed teenoor God herhaal word en die gevaar bestaan dat die erns van die aflegging daarvan teenoor God in besonder mag verlore gaan.

\section{Literatuurverwysings}

Baker, J W 1980. Heinrich Bullinger and the Covenant: The other Reformed tradition. Athens: Ohio University Press.

Bantjes, J G 1888 Journal of the Expedition of the Emigrant Farmers in D C F Moodie, The History of the Battles and Adventures of the British, the Boers, and the Zulus, \&c., in Southern Africa From the Time of Pharaoh Necho, to 1880. With Copious Chronology. Vol I, 553-569. Cape Town: Murray \& St Leger, Parliamentary Printers and Government Bookbinders.

Beukelman, J 1776. Uitgelezene keurstoffen of leerredenen, Deel I \& II. 'S Gravenhage: Jan Abraham Bouvinck.

Beukes, D P M 1971. Die Sonderlinge Gelofte, in "Hier Staan Ons ...". Geloftefeesbundel uitgegee by die geleentheid van die ingebruikneming van die gerestoureerde Slagveld van Bloedrivier 9-10.

Blanke, E \& Leuschner, I 1990. Heinrich Bullinger: Vater der Reformierten Kirche. Zürich: Theologischer Verlag.

Boekspiezl van Suid-Afrika 1952. Katalogus van 'n uitstalling van boeke, atlasse en kaarte in die Suid-Afrikaanse Biblioteek, Kaapstad 1 Maart tot 5 April 1952. Herdruk met nuwe plate 1981.

Bosman, I D 1938. Onderwys en die Groot Trek. Die Huisgenoot, Desember, 159, bl 177.

Brakel W à 1739. Redelyke Godtsdienst. $14^{\circ}$ Druk. Rotterdam: Wed. H van den Aak. 
Bres, Guy de 1562. Le baston de la foy chrestienne, propre pour renbarrer les ennemis de l'Euangile ... Imprime à Lyon.

Brueggemann, W 1982 Genesis. Interpretation: A Bible Commentary for Teaching and Preaching. Atlanta, Georgia: John Knox Press.

Bullinger, H 1621. Huys-boeck Utrecht: Gedruk deur Abraham van Herwijck vir JanEvertsen Cloppenbosch.

Cachet, F L 1882. De Worstelstrijd der Transvalers. $2^{\circ}$ Druk. Amsterdam: Höveker en Zoon.

Callenbach, J R 1897. Justus Heurnius eene bijdrage tot de geschiedenis des Christendoms in Nederlandsch Oost-Indiex. Nijkerk.

Carstens, R \& Grobbelaar, P W 1988. Voortrekkerlewe: Agter die skerms op die Groot Trek. Johannesburg.

Christelijke Encyclopaedie 1931. Sjoerds (Foeke) in Deel VI, 378(2)-379(1).

Coetzee, J Chris 1941. Onderwys in Transvaal 1838 - 1937. Pretoria: J L van Schaik, Bepk.

De Jongh P S 1977. Die lewe van Erasmus Smit. Kaapstad, Pretoria: HAUM.

De Jongh, P S 1987. Sarel Cilliers: 'n Biografie oor die Voortrekkerfiguur Sarel Cilliers. Johannesburg: Perskor.

D'Outrein J 1752. Het gouden kleinoot van de leere der waarheid. $\tau^{\circ}$ Druk. Amsterdam: Nicolaas Byl.

Dreyer, W A 1999. Nederduitsch Hervormde Kerk van Afrika - die eerste 250 jaar, 1652-1902. Pretoria: Kital.

Du Toit, H D A 1947. Predikers en hul prediking in die Nederduitse Gereformeerde Kerk van Suid-Afrika. DD-proefskrif, Universiteit van Pretoria.

Du Toit, S 1947. Die Geskiedenis van die Gereformeerde Kerk, in Kultuurgeskiedenis van die Afrikaner, Deel II. Kaapstad: Nasionale Pers Beperk.

Duvenage, G D J 1988. Die Groot Trek - die eerste drie jaar, Deel 3:1838, die Gelofte. Johannesburg: Afrikanervolkswag.

Engelbrecht, S P 1920. Geschiedenis van de Nederduits Hervormde Kerk in Zuid-Afrika, Deel I. Amsterdam en Pretoria: J H de Bussy. 
Flemming, H C J 1971. Vreugde by Geloftevervulling, in "Hier Staan Ons." Geloftefeesbundel uitgegee by die ingebruikneming van die gerestoureerde Slagveld van Bloedrivier 15-16.

Gerdener G B A 1919. Sarel Cilliers die vader van Geloftedag. Stellenbosch.

Hanekom, T N 1951. Die Liberale Rigting in Suid-Afrika - 'n kerkhistoriese studie, Deel

I. Stellenbosch: CSV-Boekhandel.

Hellenbroek A 1729. De evangelische Jesaia, Deel II. $3^{\circ}$ Druk. Rotterdam: Reinier van Doesburg.

Hellenbroek A 1734. Bybelsche keurstoffen, Deel II. Amsterdam: Adrianus Douci.

Hofstede HJ 1876. De Geschiedenis van den Oranje-Vrijstaat. Den Haag.

Kestell, J D 1920. Die Voortrekkers. Tweede Uitgawe. Pretoria, Amsterdam: Holl.Afrik. Uitgevers-Mij. V/h J. Dusseau \& Co.

Kestell, J D 1938 Voortrekkers wat ek geken het. Die Huisgenoot, Desember, bl 147, 149.

Kestell, J D \& Hofmeyr, N 1898. De Voortrekkers of Het Dagboek van Izak van der Merwe. Amsterdam, Pretoria: Hoveker \& Wormser.

Koning, M 1722. Lexikon Hieroglyphicum Sacro-Profanum, of Woordboek van Gewyde en Ongewyde Voor- en Zinnebeelden, Waarin Persoonen, Daden, Tyden, Plaatsen, Dieren, Boomen, Planten, Kruiden, Visschen, Deel I-II. Dordrecht en Amsterdam: Johannes van Braam en Gerard Onder De Linden.

Kruger, B R 1957. Die ontstaan van die Gereformeerde Kerk in Suid-Afrika. Pretoria: V \& R Drukkery.

Liebenberg, B J 1977. Andries Pretorius in Natal. Pretoria en Kaapstad: Academica.

Lugtenburg, A H 1925. Geskiedenis van die Onderwys in die S. A. Republiek (1836 1900). Pretoria: Van Schaik.

Malan, C J 1981. Die Nadere-Reformasie. Potchefstroom: PU vir CHO.

Malan, J H 1913. Boer en barbaar of die lotgevalle van die Voortrekkers viral tussen die Jare 1835 en 1840. Unie Lees- en Studie-Biblioteek, No 27. Potchefstroom: "Het Westen"-Drukkerij.

Mans, C J 1967. Die draagkrag van die Geloftes van 1838 en 1880. HTS 22(4).

Marck, J a 1730. Het merch der Christene Got-geleertheit. $3^{\mathrm{e}}$ Druk. Rotterdam: Nicolaas en Paulus Topijn. 
McCoy, C S \& Baker, J W 1991. Fountainhead of Federalism - Heinrich Bullinger and the Covenantal Tradition. With a translation of De testamento seu foedere Dei unico et aeterno (1534). Louisville, KT: Westminster.

Nel, L J 1939. Uit die Voortrekkertyd: Herinneringe van Louis Jacobus Nel. Pretoria: Van Schaik.

Pont, A D 1988. Die Gelofte van 1838 - 'n poging om die teologiese agtergrond daarvan te peil, in Die Gelofie van 1838. Pretoria: Kital.

Potgieter, C \& Theunissen, N H 1938. Kommandant Hendrik Potgieter. Johannesburg: Afrikaanse Pers Beperk.

Preller, G 1918. Herinneringe van Lourens Christiaan de Klerk, in Scripta Africana Reeks, II: Die Groot Trek. Voortrekkermense, I. (Faksimilee publikasie van die werk soos dit in 1918 verskyn het).

Pretorius, J C 1988. Op Trek: Die daaglikse lewe tydens die Groot Trek. Pretoria: Scripta Africana.

Raath, A W G 1999. Federale teonomie: Die impak van die federale teologie op die publieke regslewe van die vroę Kaapse volksplanting (1652-1708), deel 1. Tydskrif vir Regswetenskap 24(2).

Raath, A W G 1999 a. Die Huisboek van Heinrich Bullinger. Konteks 10(2).

Raath, A W G 2000. Die Skatboek van Zacharias Ursinus. Konteks 11(1\&2).

Raath, A W G 2000a. Wilhelmus à Brakel se werk oor die redelike Godsdiens. Konteks, 11(3).

Schoeman, K 1995. Die Wêreld van Susanna Smit 1799-1836. Kaapstad: Human en Rousseau.

Sjoerds, F 1761. Kort Vertoog van den Staat en de Geschiedenissen der Kerke, van de Scheppinge tot op Christus, deel 1. Leeuwarden: Pieter Koumans.

Smit, S 1839-1863. Dagboeke. Ongepubliseende bronne in die Voortrekkermuseum, Pietermaritzburg.

Smytegelt, B 1780. Des Christens eenige troost in leven en sterven. Amsterdam: Johannes Allart.

Spoelstra, B 1922. Ons Volkslewe: Kultuur-Historiese Leesboek. Pretoria: Van Schaik. Spoelstra, B 1963. Die "Doppers" in Suid-Afrika 1760-1899. Johannesburg: Nasionale Boekhandel. 
Spoelstra, C 1906. Bouwstoffen voor geschiedenis der Nederduitsch-Gereformeerde Kerken in Zuid-Afrika, Deel I, II. Amsterdam, Kaapstad.

Storm, J M G 1988. 'n Biografiese skets van Sarel Cilliers - die geestelike vader van die Gelofte, in Pont, A D (red), Die Gelofte van 1838. Pretoria: Kital.

Storm, J M G 1989. Die Voortrekkerkerk 1836-1853. Pretoria: Kital.

Strauss, L J 1986. Ekklesiologie van W à Brakel. 'n Poging om die grondslag van die kerkbegrip van die Voortrekkers vas te stel. BD-skripsie, Universiteit van Pretoria.

Strauss, P 1994. Geloftedag in die "Nuwe" Suid-Afrika. Bloemfontein: Druforma.

Trommius, A 1750. Volkomene Nederlandsche Concordantie, Deel I, A-G. Leeuwarden: Pieter Koumaris, Willem Coulon, Abraham Ferwerda.

Ursinus, Z 1641. Schat-boeck. Leiden: Johannes Spiljardus.

Ursinus, Z 1685. Schat-boeck. Amsterdam: Pieter Frans.

Van der Walt, A J 1920. Vastrappers. Potchefstroom: A H Koomans Beperk.

Van der Watt, P B 1981. Die Voortrekkers se leesstof. Voorligter, Oktober.

Van Selms, A 1986 Genesis, Deel I. Vierde Druk. Nijkerk: G F Callenbach BV. (POT.)

Van Zijl, W J 1991. Van Skeepskis na Wakis tot Boekrak. Lux Verbi.

Vorster, J D 1956. Die kerkregtelike ontwikkeling van die Kaapse Kerk onder die Kompanjie, 1652-1792. Potchefstroom: Pro Rege.

Venter, A A 1971 Die Grondslag van die Gelofte in "Hier Staan Ons," 10-11. Geloftefeesbundel uitgegee by geleentheid van die ingebruikneming van die gerestoureerde Slagveld van Bloedrivier.

Venter, E A 1982. Ons geskiedenisalbum. Johannesburg: Perskor.

Voigt, J C 1899. Fifty years of the history of the Republic in South Africa 1795-1845, Vol II. London: T. Fischer Unwin.

Voortrekkermuseum, Pietermaritzburg 1982. Voortrekkermuseum Pietermaritzburg, 1840. Pietermaritzburg: Voortrekkermuseumraad. 